\title{
Winter weather conditions vs. air quality in Tricity, Poland
}

\author{
Jadwiga Nidzgorska-Lencewicz • Malgorzata Czarnecka
}

Received: 12 July 2013 / Accepted: 9 February 2014 / Published online: 12 March 2014

(C) The Author(s) 2014. This article is published with open access at Springerlink.com

\begin{abstract}
The principal aim of this paper is to assess the influence of meteorological conditions on the variability of sulfur dioxide and PM10 particulate matter concentration of pollutants during winter with consideration of an excess of admissible standards. The basis for the analysis were hourly concentrations of PM10 and sulfur dioxide as well as the basic meteorological elements automatically recorded at five stations located in the Tricity agglomeration, and operating within the weather station network belonging to the Agency of Regional Air Quality Monitoring in the Gdańsk Metropolitan Area (ARMAAG). The analysis covers the calendar winters (December-February) in the years 2004/2005 through $2009 / 2010$. The variability of the concentrations of both pollutants under certain weather conditions, i.e. air temperature and relative humidity, atmospheric pressure, as well as wind speed and direction, were evaluated by means of cluster analysis using $k$-means belonging to a group of nonhierarchical cluster analysis method. The composite effect of meteorological conditions on the variability of sulfur dioxide and PM10 concentrations in isolated clusters were determined by multiple linear regression, using a stepwise procedure, at the significance level $\alpha=0.05$ and $\alpha=0.01$. The effect of individual weather elements on the pattern of concentration levels was determined using partial regression coefficients. Clusters grouping the highest concentrations of pollutants were characterised, in most cases, by the lowest air temperature and a lower wind speed, and often a higher pressure, and sometimes slightly lower relative air humidity, i.e. the conditions of anticyclonic weather. Weather conditions had a statistically significant effect on the concentrations of both
\end{abstract}

J. Nidzgorska-Lencewicz $(\bowtie) \cdot$ M. Czarnecka

Department of Meteorology and Green Areas Management, West

Pomeranian University of Technology in Szczecin, ul. Papieża Pawła

VI 3A, 71-459 Szczecin, Poland

e-mail: Jadwiga.Nidzgorska-Lencewicz@zut.edu.pl pollutants in all clusters; however, air temperature and wind speed had the crucial role. Thermal conditions were the decisive factor in the winter season 2005/2006 with the most frequent, overnormative daily particulate matter concentration, yet the inversion layers both lower and upper, occurring almost every day in January 2006 also had a significant influence.

\section{Introduction}

Air quality during the cold seasons of the year is primarily determined by the concentration of suspended particulate matter and sulfur dioxide, which both result from increased emission from heating systems. The main reason behind their emission is the lack of significant changes in the structure of energy sources and their consumption. The basic primary energy carrier in national economy, like in many other countries particularly in Eastern Europe, is hard coal. According to data from $2007,51 \%$ of renewable energy comes from hard-coal burning and $14 \%$ from brown coal (http://www.gios.gov.pl/). Almost half of 8-9 million households use local coal-burning heating plants and household furnaces (Nilsson et al. 2006). Households are heated using coal of low quality, with high sulfur and ash content and hence of low heating parameters in worn out furnaces which are often unsuitable for the purpose, and this fact is a significant problem in the so-called low emission. Special analysis of the chemical composition of particulate matter from episodes of smog which occurred in Kraków, one of the most polluted cities in Poland, allowed for identification of their sources (Mira-Salama et al. 2008). According to the authors, over $70 \%$ share of coal in individual particles and relatively low percentage of particles containing sulfate and chlorine at the beginning of the smog episode clearly suggest that the main source of high concentration of particulate matter are processes related to coal burning, both 
industrial and in households. The effect of traffic on particulate matter concentration during severe smog episodes proved to be slight.

Seaport activities constitute an extensive load for both marine and urban environment. The source of emission include the operation of engines of ships at berth, haulers and other vessels operating in harbour basins, cargo handling in port, port investments, the intensity and structure of port facilities, as well as production and service activities in port area (Borkowski et al. 2012). In 2005, shipping was responsible for $39 \%$ of sulfur dioxide emission in the European Union, and it is estimated that by 2020 the emission of $\mathrm{SO}_{2}$ and NOx by ships will have exceeded emissions from all land sources (Commission to the Council and the European Parliament 2005). In 2010, the estimated $\mathrm{SO}_{2}$ emission from transport, namely from two sources jointly: road transport and other vehicles and devices, amounted to $1,877.386 \mathrm{Mg}$. Maritime shipping was responsible for $21 \%$ of $\mathrm{SO}_{2}$ emission and for $1 \%$ in case of particulate matter PM10 (Raport KOBIZE 2012).

The concentrations of particulate matter and sulfur dioxide clearly follow the seasonal structure pattern. In Poland, during the heating season, the concentrations of the two pollutants are, on average, 1.5 to two times higher than in the summer, and, during harsh winters and at poor dispersion conditions, even three to five times higher. Moreover, the average particulate matter concentration in cities is approximately two times higher than in the suburban areas. However, while the concentrations of $\mathrm{SO}_{2}$ in Poland are generally within the acceptable range, the concentration of a particulate matter is the most frequent cause of violations of the air quality standards. In 2007, the index of exposure to overnormative influence of PM10 particulate matter was higher in Poland than the mean calculated for the European Union (Główny Inspektorat Ochrony Środowiska 2010).

In 2010, excessive 24-h PM10 concentrations were observed in $92 \%$ of zones in Poland, whereas excessive annual concentrations were observed in half of the zones (PMŚ 2011). Overnormative particulate matter concentration occurs most frequently in southern Poland. In extremely cold January of 2006, mean hourly concentration of PM10 in Kraków exceeded $500 \mu \mathrm{g} \cdot \mathrm{m}^{-3}$ three times (Czarnecka and Nidzgorska-Lencewicz 2011) which was by $100 \mu \mathrm{g} \cdot \mathrm{m}^{-3}$ more than the maximum PM10 concentration recorded a year before during smog episode classified by Mira-Salama et al. (2008) as severe smog episode. High concentrations of particulate matter cause an important and yet unsolved problem in many European countries such as Italy, Slovakia, the Balkan region, Turkey and several other urban regions. In 2010 , about $21 \%$ of the urban population in the EU was exposed to PM10 above the limit value (EEA 2012). In the Netherlands, mean annual concentrations range from 20 to $50 \mu \mathrm{g} \cdot \mathrm{m}^{-3}$, yet there is a four- to fivefold increase during smog episodes (van der Wal and Janssen 2000). In the period
2005-2009, mean annual concentration of particulate matter in Istanbul was from 46 to $70 \mu \mathrm{g} \cdot \mathrm{m}^{-3}$ and the daily standard was exceeded on a regular basis; in some regions, it was exceeded in more than $90 \%$ of days in a year (Unal et al. 2011). PM1 0 measurement series of 1 year duration in Athens showed that the percentage of 24-h admissible value of $50 \mu \mathrm{g}$. $\mathrm{m}^{-3}$ was exceeded in $11.5-91.5 \%$ of cases at four sites (Grivas et al. 2004). During the episodes of high particulate matter concentration in four European cities, the maximum daily concentrations amounted to $130 \mu \mathrm{g} \cdot \mathrm{m}^{-3}$ in London, approximately $250 \mu \mathrm{g} \cdot \mathrm{m}^{-3}$ in Oslo and Helsinki and around $400 \mu \mathrm{g} \cdot \mathrm{m}^{-3}$ in Milan (Kukkonen et al. 2005).

Deterioration of air quality is usually connected with unfavourable atmospheric conditions, less so with sudden emission increase the amount of which, in case of pollution resulting from heating processes, is the consequence of their intensity as a result of the fall in temperature. The effect of weather on the dispersion of gases and particulate matter, or on their retention in the ground layer of air, has been widely demonstrated. One can learn from the topic literature that certain weather patterns support dispersion of pollution and, therefore, are positive to atmosphere's self-cleaning; others, however, pose a risk of increased concentration of pollutants around the place of their emission. Most frequently, problems with this accumulation affect urban areas where adverse health effects are likely to involve a large proportion of the population. There is extensive literature on the impact of pollution on human health, especially when it comes to abnormally high concentrations. In the year 2000 alone, 0.8 million deaths in the whole world were attributed to poor air quality and a further 7.9 million people suffered from respiratory system disorders, lung diseases and cancer (WHO 2002). The noxious effects of particulate matter on the human body represent a well-studied area. Numerous published research reports declare that the concentration level of this pollutant is well correlated with morbidity that requires hospital care and even mortality caused by escalation of respiratory and circulation system disorders (Brunekreef and Holgate 2002; Dominici et al. 2006; Freitas et al. 2010; Kappos et al. 2004; Lazaridis 2011; Medina et al. 2004; WHO 2005). According to the assessment by Tainio et al. (2010), the anthropogenic emission of primary fine particulate matter PM 2.5 in Europe causes a few thousand premature deaths a year in Poland. It is a consequence of emission in Poland as well as the transport of particulate matter from other European countries, roughly in equal ratio. In the European Union, average life expectancy is estimated to be 8.6 months lower due to exposure to PM 2.5 resulting from human activities (WHO 2008).

Particularly unfavourable conditions of pollution dispersion are connected with steady high pressure which brings cloudless weather or small cloudiness with slight wind speed or calm and constant balance in the lower part of the boundary layer of atmosphere. The literature on the subject describes 
winter seasons or episodes of increased or very high concentration of pollution, primarily PM10, which occurred in the conditions of anticyclonic weather marked by freezing weather and constant balance in the lower part of the boundary layer of atmosphere (Czarnecka and Nidzgorska-Lencewicz 2011; Cheng et al. 2007; Demuzere et al. 2009; DrzenieckaOsiadacz and Netzel 2010b; Grivas et al. 2004; Kassomenos et al. 2003; Malek et al. 2006; Greene et al. 1999; Kukkonen et al. 2005; Mira-Salama et al. 2008; Unal et al. 2011; van der Wal and Janssens 2000). In such conditions, the greatest risk of the increase of concentration of pollutants is connected with inversions of temperature often occurring during 24-h periods (Drzeniecka-Osiadacz and Netzel 2010a; İçağa and Sabah 2009; Kuznetsova et al. 2008; Silva et al. 2007; Wallace et al. 2010). Temperature inversions, isotherms and layers of slight vertical temperature gradient which develop most often in the conditions of high-pressure weather create definitely the most unfavourable conditions for pollutants to disperse as they constitute layers which inhibit diffusion and affect the characteristics and evolution of the urban aerosol (Lazaridis 2011; Olofson et al. 2009). Inversion layers are marked by usually minor vertical and horizontal air replacement, yet the role of upper and lower inversions in the shaping of the concentrations of pollutants is essentially different. The lower inversions directly affect the amount of concentration of pollutants, especially from lower sources whereas the upper inversions constitute a barrier limiting the upward dispersion of pollutants which is significant in the situations when an unstable balance occurs below-usually in the day time. A 6year research on the condition of the boundary layer during the winter months conducted with the use of sodar in Kraków (Godłowska et al. 2008) showed the connection between concentration of pollutants $\mathrm{SO}_{2}, \mathrm{PM} 10, \mathrm{CO}, \mathrm{NO}, \mathrm{NO}_{2}$ and $\mathrm{NO}_{\mathrm{X}}$ and the altitude of convection. İçağa and Sabah (2009) proved that there is a strong influence of inversion on $\mathrm{SO}_{2}$ and PM10 in Afyon (Turkey) in connection with air temperature. The analysis of the results of a 15-year observation indicates that in Prague the depth of the base of inversion and time of occurrence had the strongest influence on concentration of pollutants, whereas the influence of the depth and intensity of inversion was markedly smaller (Knozowa 2008).

The studies which aim to identify the weather conditions in which there is a significant increase in concentration of pollutants include the analysis of basic and customarily measured meteorological elements (mainly temperature, relative air humidity, wind speed and direction and less often atmospheric pressure, the amount and duration of precipitation). The results presented in the literature on the subject differ according to region, adopted observation period (from single episodes to observation series which last several years and longer), the type of pollution, climatic zone, season and local topographic conditions. The differences can involve precision of correlations, but also the sign of relationship and can result from adopted more or less advanced methods of analysis.

During the winter period, concentration of pollutants shows a strong and explicitly negative relationship with air temperature. The results of many studies confirm a positive, ventilation part that wind plays despite lower speed during anticyclonic weather and in a built-up area (Czarnecka and Nidzgorska-Lencewicz 2011; Drzeniecka-Osiadacz and Netzel 2010b; Grivas et al. 2004; Ocak and Turalioglu 2010; Pires et al. 2008; Zabalza et al. 2007). In Istanbul, the average PM10 concentration level calculated for wind speed $\geq 4.5 \mathrm{~m} \cdot \mathrm{s}^{-1}$ was about half that at wind speed below $1 \mathrm{~m} \cdot \mathrm{s}^{-1}$ both in the conditions pressure lower as well as higher than 1,018 hPa (Unal et al. 2011). Different directional coefficients characterising the relationship between concentration of pollutants and wind speed in the analysed episodes of an increased PM10 concentration in four European cities were obtained by Kukkonen et al. (2005) and Vardouulakis and Kassomenos (in Ocak and Turalioglu 2010).

Many studies point to statistically significant role of relative humidity in the description of variability of concentration of pollutants, yet the results concerning the sign of this relationship are divergent. Positive relationship between $\mathrm{SO}_{2}$ and PM10 was shown by İçağa and Sabah (2009). Distinctly negative correlations of $\mathrm{SO}_{2}$ concentrations, but also those of PM10, with relative humidity, were demonstrated by Freitas et al. (2010), Pires et al. (2008), Czarnecka and Nidzgorska-Lencewicz (2011), and sulfur dioxide concentrations alone in the winter months, from December to February, were shown by Cuhudaroglu and Demirci (1997). On the other hand, the results reported by Elminir (2005) for Egypt indicate significantly higher annual average concentrations of both pollutants (particulate matter even twice) under high, more than $80 \%$ relative humidity. However, a month-bymonth analysis reveals that the positive correlation of PM10 concentration and relative humidity is also visible in all the months from December to February, whereas for sulfur dioxide, the sign of the correlation in January and February was negative. Ocak and Turalioglu (2010) obtained divergent correlation coefficients, depending on the type of pollutant and the period under study.

The studies concerning the influence of precipitation on aerosanitary conditions of air are scarce, and the calculated coefficients of correlations are slight and as a rule insignificant (Godłowska et al. 2008; van der Wal and Janssen 2000). The results which indicate the efficiency of precipitation in decreasing the concentration levels of particulate matter were presented by İçağa and Sabah (2009), as well as Czarnecka and Nidzgorska-Lencewicz (2010).

The results of the research on the effect of climate changes on a future level of pollution (e.g. Giorgi and Meleux 2007; Jacob and Winner 2009) do not inspire optimism. Simulations 
carried out by Huszar et al. (2011) for Central and SouthEastern Europe demonstrate that the changing climate will be followed by deteriorated air quality, not only due to possibly increased $\mathrm{O}_{3}$ concentrations, but also as a result of an expected growth in $\mathrm{SO}_{2}$ levels, with relatively low changes in PM10 concentrations. The ways of tackling these negative trends include restructuring of urban space and amelioration of the topoclimate of the city. All this led us to undertake the attempt to identify the meteorological elements accompanying certain $\mathrm{SO}_{2}$ and PM10 changes, which is part of the most topical issues related to air quality of urban areas.

\section{Materials}

\subsection{Study area}

Tricity is a polycentric metropolitan area located on Gdańsk Bay, northern Poland. Its urban area is composed of three neighbouring and interlinked cities: Gdynia, Sopot and Gdańsk, occupying a total area of $414 \mathrm{~km}^{2}$, hosting a population of 742,400 inhabitants. The main municipality is Gdańsk, which covers the largest area and is inhabited by the largest population. Gdańsk is also the seat of the authorities of the Pomeranian (Pomorskie) Voivodeship. Sopot, on the other hand, is the smallest urban area having, however, the highest population density. The economy of Tricity heavily relies on the maritime industry, including shipbuilding. The port of Gdynia is of primary importance to Polish economy and the port of Gdańsk is an important international communication junction. According to the current strategy of the European Union, it is of significant importance as a part of the European Transport Corridor which connects Scandinavian countries with Southeast Europe. Besides two largest shipyards in Gdańsk and Gdynia, there are five other, highly specialised shipyards, namely the Gdańsk Ship repair Yard "Remontowa", Północna Shipyard (producing rescue and scientific vessels), Wisła (inland and coastal vessels), Gdyńska Ship repair Yard and Naval Shipyard (shipbuilding). Besides the shipbuilding industry, electromechanical and petrochemical industries - as in any large urban agglomerations - road transport, power and heating facilities represent important sources of air pollution.

According to the synthetic report of the Inspectorate for Environmental Protection (2011), the levels of PM10 concentration recorded during episodes in Tricity are in comparable degree caused by industrial facilities in Gdańsk, small industrial facilities, municipal and traffic emission, sources in Sopot and Gdynia and, above all, sources in towns to the south of Gdańsk. The estimated assessment of the highest concentrations of PM10 caused by distant sources is within the range of $35-50 \mu \mathrm{g} \cdot \mathrm{m}^{-3}$ depending on the region of the origin of particulate matter. Marine aerosol can have some influence on the concentration of particulate matter. The occurrence of marine aerosols is connected with storms caused by translocating atmospheric fronts in low pressure system and with local breeze circulation.

\subsection{Meteorological station network and data}

The materials used in this study involved measurements of pollutant concentration and basic meteorological elements from five automatic air quality measuring stations located in the Tricity agglomeration. The data were provided by courtesy of the Agency of Regional Air Quality Monitoring in the Gdańsk Metropolitan Area (ARMAAG). The primary data comprised the hourly concentrations of sulfur dioxide and particulate matter (PM10), air temperature and relative humidity, atmospheric pressure as well as wind speed and direction, collected during the calendar winters (December-February) of the years 2004/2005-2009/2010. Data on particulate matter concentration levels came from five stations, while that on sulfur dioxide - from four stations-is shown in Fig. 1. Gdynia and Gdańsk are represented by two stations each, and one is located in Sopot. Although all these are defined as urban background stations, those in Gdańsk-Wrzeszcz and Gdynia-Pogórze are located in residential areas; GdańskJasień, among scattered, low-building housing quarters; Sopot in allotment area and the Gdynia-Sródmieście station is located on the harbour waterfront.

The sets of basic hourly data regarding sulfur dioxide comprised 50,172 elements for each variable, and regarding particulate matter comprised 61,027; the lack of data (3 and $6 \%$, respectively) was caused, for the most part, by discontinuity in recordings of atmospheric pressure and, at times, wind speed.

\section{Methods}

We used cluster analysis to estimate the diversity in the concentration of sulfur dioxide and PM10 depending on the weather conditions. Cluster analysis is a statistical classification method used to identify homogeneous subgroups in a population and gather them into sets of data basing on their similarity (Gerstengarbe and Werner 1997). As a reliable and relatively simple method of classification, clustering is also used in studies on air quality, with hierarchical clustering being used most commonly (Yonemura et al. 2008; Yoo et al. 2011; Unal et al. 2011). However, in this paper, we use the $k$-means clustering, which belongs to a group of nonhierarchical cluster analysis methods. The implemented mechanism, based on the $v$-fold cross-validation, allowed identification of the optimal number of segments which are combinations of concentration of pollutants and meteorological elements. The analysis of wind speed was based on Knoch's 
Fig. 1 Location of the measuring stations

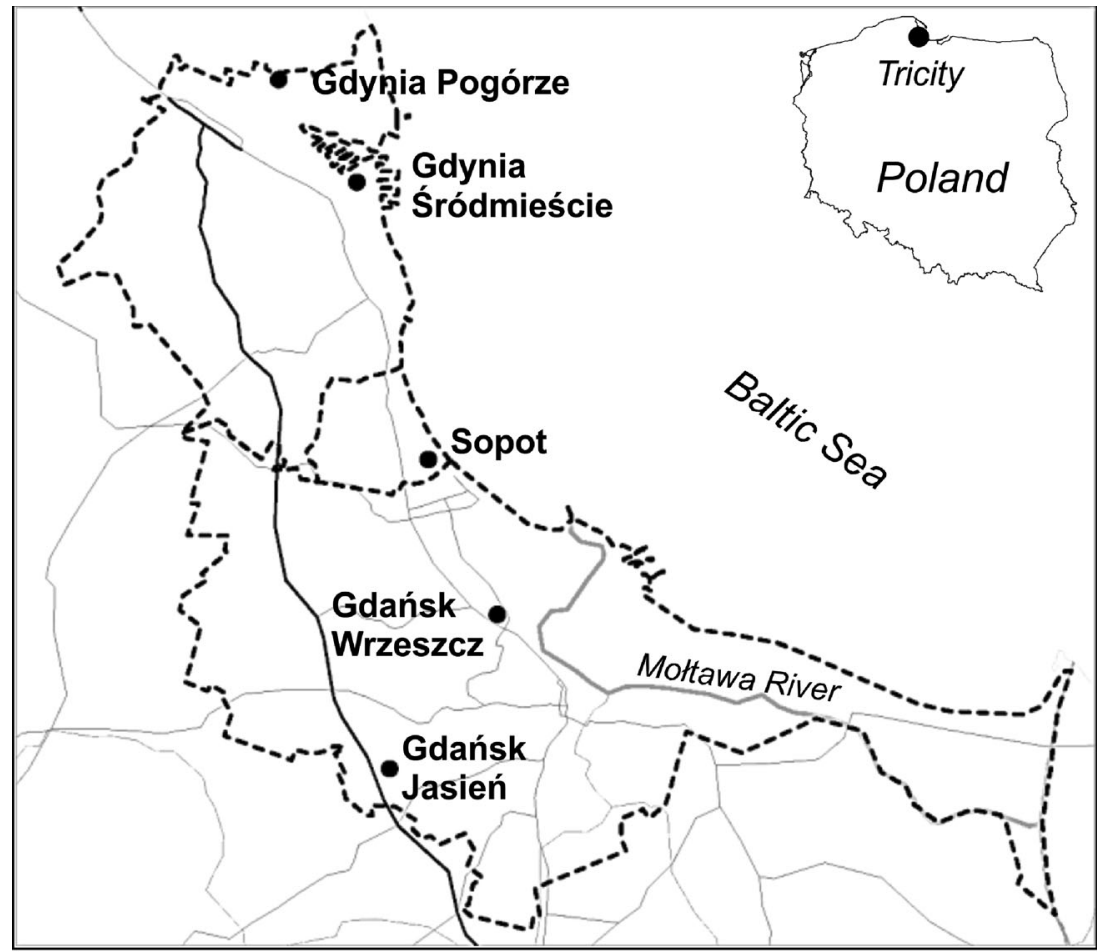

roads

----- administrative boundaries of cities

class (in Kozłowska-Szczęsna et al. 1997) which determines the speed in four ranges as: $0-1 \mathrm{~m} \cdot \mathrm{s}^{-1}$, calm; $1-4 \mathrm{~m} \cdot \mathrm{s}^{-1}$, weak wind; $4-8 \mathrm{~m} \cdot \mathrm{s}^{-1}$, moderate wind; over $8 \mathrm{~m} \cdot \mathrm{s}^{-1}$, strong wind. Threshold values adopted in this classification 1 and $4 \mathrm{~m} \cdot \mathrm{s}^{-1}$ are significant criteria in terms of evaluation of the ventilation purpose of this element. According to Hutchinson (in Lewińska 2000), the wind conditions below $1 \mathrm{~m} \cdot \mathrm{s}^{-1}$ occurring with frequency of more than $90 \%$ sufficient ventilation is less probable and in turn the increase of air turbulence occurs along when the wind speed $4 \mathrm{~m} \cdot \mathrm{s}^{-1}$ (Parczewski quoted by Kozłowska-Szczęsna et al. 1997) is exceeded.

For the assessment of aerosanitary conditions, the Common Air Quality Index (CAQI) was used - the index is available on www.airqualitynow.eu. The index was formulated within the framework of CITEAIR project according to air quality standards in European Union. Due to the fact that during the winter season, PM10 particulate matter concentration levels is the greatest threat to air quality, this paper includes in the index concentrations of this pollutant only. Hourly values of PM10 particulate matter correspond to the following CAQI (urban background index) values: $0-25 \mu \mathrm{g} \cdot \mathrm{m}^{-3}$, very low; $25-50 \mu \mathrm{g}$. $\mathrm{m}^{-3}$, low; 50-90 $\mu \mathrm{g} \cdot \mathrm{m}^{-3}$, medium; 90-180 $\mu \mathrm{g} \cdot \mathrm{m}^{-3}$, high; $>180 \mu \mathrm{g} \cdot \mathrm{m}^{-3}$, very high (van den Elshout et al. 2013).

The complex influence of meteorological conditions on the variability of concentration levels of the analysed air pollution items for selected segments were determined by linear multiple regression, using a stepwise procedure, at the significance level $\alpha=0.05$ and $\alpha=0.01$. The contributions of individual weather elements in explaining the size of the concentrations were determined using the partial regression coefficients. All calculations were performed using the Polish version of STATISTICA 10 software.

For the evaluation of the frequency of temperature inversion, the results of corresponding measurements timed 00 UTC and 12 UTC from the Aerological Station in Leba, located approximately $90 \mathrm{~km}$ to the north-west of Tricity metropolitan area - data available on www.weather.uwyo. edu/upperair/sounding.html. The basis for the assessment of the concentrations of the pollutants under study was the Regulation of the Minister of Environment of 24 August 2012 on the level of some substances in air.

\section{Results and discussion}

In the winter seasons (December-February) of the years 2004/2005-2009/2010, the average sulfur dioxide concentrations ranged from 6.5 to $8.5 \mu \mathrm{g} \cdot \mathrm{m}^{-3}$, while PM10 ranged from about 28 to $49 \mu \mathrm{g} \cdot \mathrm{m}^{-3}$ (Fig. 2). Slightly higher air pollution level by sulfur dioxide was found in Gdynia-Pogórze, whereas the concentration of PM10 in Gdynia-Śródmieście was about $60 \%$ higher than in the other districts. In most parts of Tricity, 
Fig. 2 Mean sulfur dioxide and particulate matter PM10 concentrations during calendar winter (December-February). Years 2004/2005-2009/2010

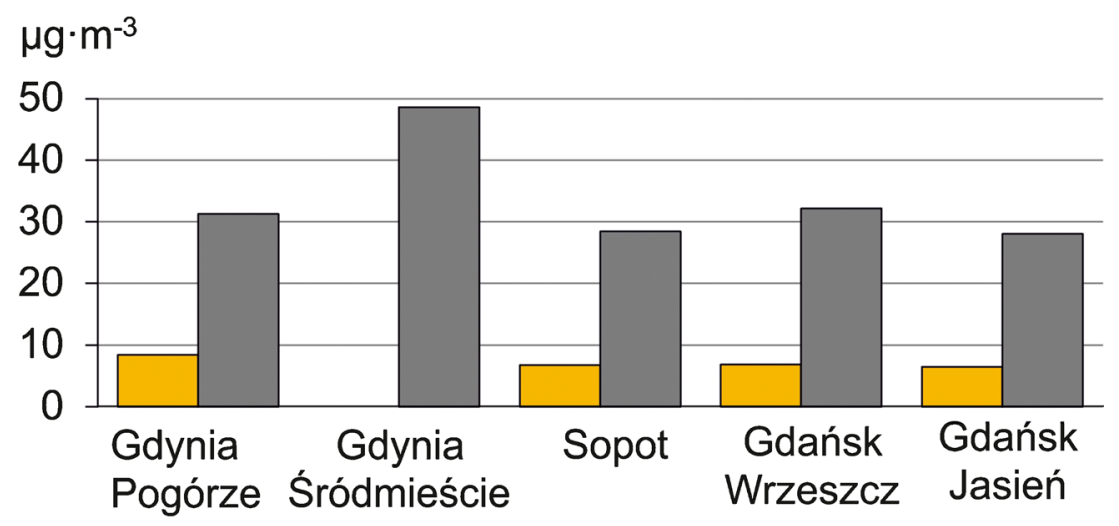

sulphur dioxide

\section{particulate matter PM10}

$\mathrm{SO}_{2}$ concentrations not exceeding $10 \mu \mathrm{g} \cdot \mathrm{m}^{-3}$ accounted for more than $75 \%$ of cases, and among them the majority were concentrations below $5 \mu \mathrm{g} \cdot \mathrm{m}^{-3}$ (Fig. 3). Concentration of PM10 ranged generally from 11 to $20 \mu \mathrm{g} \cdot \mathrm{m}^{-3}$, which was dominant in Gdańsk, in the Jasień district. On the other hand, the concentrations of the analysed pollutants in Gdynia, the most polluted area of Tricity, showed a slightly different distribution pattern. In Gdynia-Pogórze, the concentrations of sulfur dioxide exceeding $20 \mu \mathrm{g} \cdot \mathrm{m}^{-3}$ occurred twice as often, and PM10 concentrations exceeding $80 \mu \mathrm{g} \cdot \mathrm{m}^{-3}$ occurred up to three times more frequently than in the other districts.

Mean hourly concentrations of sulfur dioxide remainedexcept for a single case-within the currently binding
Fig. 3 Frequency (\%) of occurrence of sulfur dioxide and particulate matter concentrations in the accepted ranges, during calendar winter (DecemberFebruary). Years 2004/20052009/2010
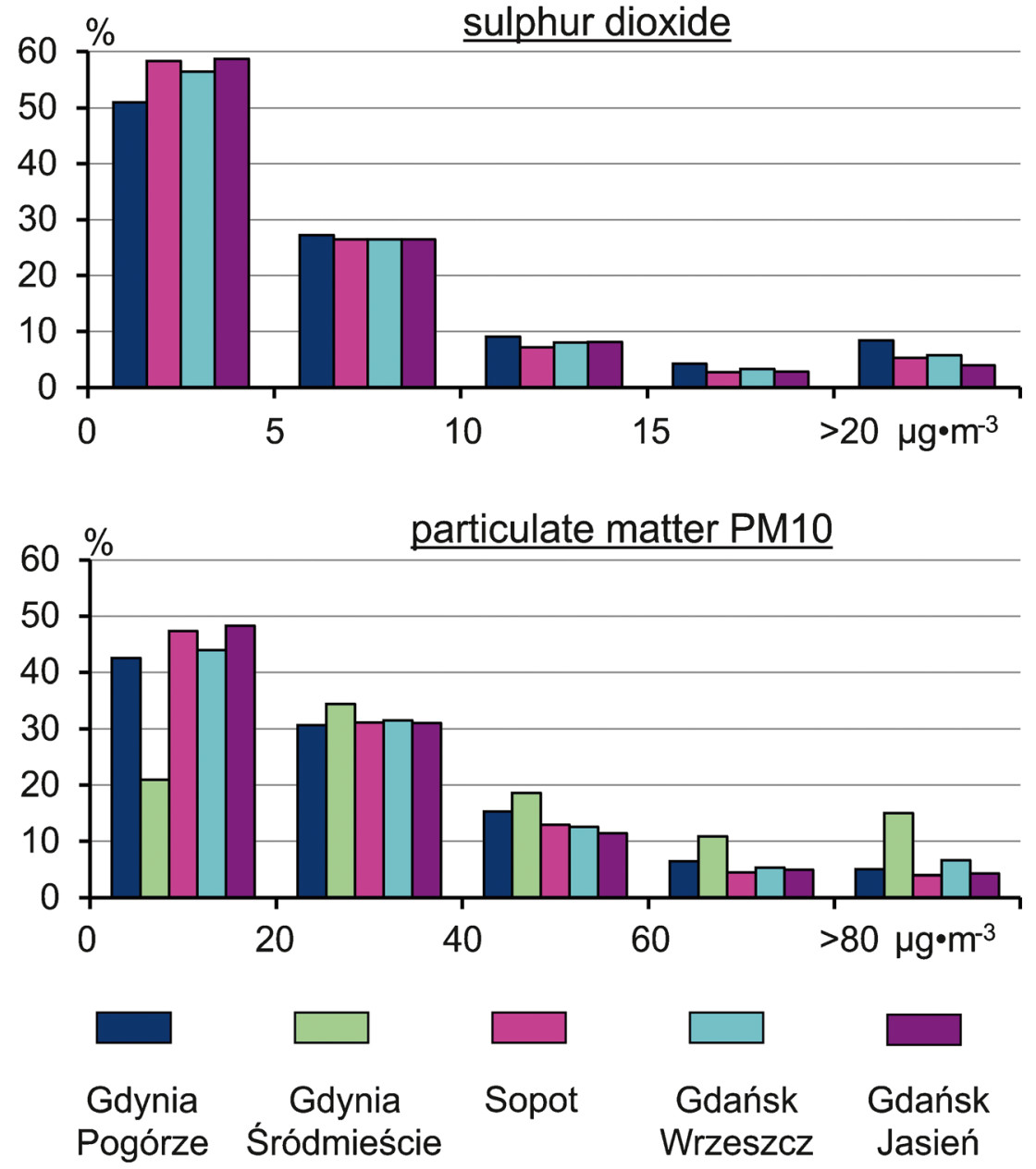
standards; however, in all the years, we recorded violations in average daily concentrations of PM10. As is shown in Fig. 4, by far, the most common excessive PM10 concentrations occurred in Gdynia-Śródmieście; in winter 2009/2010, this was nearly half days.

The highest concentrations of both pollutants and the highest number of the daily PM10 concentration standard violations were recorded in the two coldest winters, i.e. in $2005 / 2006$ and 2009/2010, when air temperatures were -1.7 and $-2.5^{\circ} \mathrm{C}$, respectively, and well below the average. In both winters, January and February were classified as very frosty and frosty, and December as normal. In the remaining winters, the average season's air temperature was above $0{ }^{\circ} \mathrm{C}$, and the warmest winter season was in 2006/2007. As a result, the concentration of both analysed pollutants - the principal source of which is burning conventional fuels for energywas in the winter of 2006/2007 lower than half of the winter in 2005/2006. In all the studied winters, Gdańsk-Jasien was by far the coldest Tricity area, while Sopot was the warmest. The aforementioned districts of Tricity were characterised by contrastive wind speed. In Gdańsk Jasień, the average seasonal wind speed was $3.3 \mathrm{~m} \cdot \mathrm{s}^{-1}$, whereas in Sopot $2.1 \mathrm{~m} \cdot \mathrm{s}^{-1}$.

The basic values classified according to the spatial clustering method included sets of hourly measurements the qualitative variable of which were four wind speed classes, and the quantitative variables included concentrations of both pollutants and data concerning air temperature, relative humidity and atmospheric pressure. By means of grouping algorithm, optimum clusters were determined depending on the district of Tricity - two to six concerning concentrations of $\mathrm{SO}_{2}$ and two to five as for PM10 concentrations; the least for Gdynia Pogórze district and the most for Gdańsk Jasień (Table 1). The clusters grouping the highest $\mathrm{SO}_{2}$ and PM10 concentrations in the predominant majority of the cases were characterised by the lowest air temperature and relative humidity and the highest or increased pressure. Such tendency indicates the high pressure weather which contributes to the intensification of heating processes and consequently to the increase in emission of the products of traditional energy sources combustion thereby weakening natural air ventilation. The significant influence of anticyclonic weather on concentration levels of the pollutants was demonstrated by Czarnecka and Nidzgorska-Lencewicz (2011), Drzeniecka-Osiadacz and Netzel (2010a), Unal et al. (2011) and Kukkonen et al. (2005). The significance of such weather conditions was slightly more marked with respect to particulate matter concentration. By far, the highest PM10 concentration registered in the conditions of the lowest temperature and relative humidity and the highest pressure were reported for cluster 2 in Gdynia Pogórze, cluster 1 in Gdynia Śródmieście and cluster 2 in Gdańsk Jasien. Large compatibility of high concentration of particulate matter occurring at the lowest temperature and increased pressure was recorded for cluster 1 in Sopot whereas in Gdańsk Wrzeszcz, despite by far lower temperature and higher pressure, cluster 2 shows the concentration of particulate matter to be markedly lower than for cluster 1 . All clusters grouping the highest concentration of $\mathrm{SO}_{2}$ were marked by the lowest average temperature but they coexisted only in Gdynia Pogórze with the highest average pressure and the lowest relative humidity. On the whole, the highest sulfur dioxide pollution was recorded in the conditions of an increased pressure - usually over $1,020 \mathrm{hPa}$. Similar weather conditions occurring simultaneously with both high as well as low sulfur dioxide and particulate matter concentrations identified clusters in Gdynia Pogórze. In the conditions of mean temperature of -2 to $-1.9{ }^{\circ} \mathrm{C}$ at relative humidity of approximately $80 \%$ and standardised pressure of $1,031 \mathrm{hPa}, \mathrm{SO}_{2}$ concentration was at the level of approximately $11 \mu \mathrm{g} \cdot \mathrm{m}^{-3}$ and concentration of particulate matter $-36 \mu \mathrm{g} \mathrm{m}^{-3}$, whereas the rise in temperature to around $3{ }^{\circ} \mathrm{C}$ and humidity to $90 \%$ with simultaneous fall in pressure to $1,012 \mathrm{hPa}$ resulted in clear decrease in $\mathrm{SO}_{2}$ and particulate matter concentration. The comparison of mean concentration values of both pollutants and analysed meteorological elements in the clusters under study shows that the most unfavourable weather conditions which cause a risk of the highest $\mathrm{SO}_{2}$ and PM10 concentrations in the districts: Gdańsk Jasień and Gdynia Śródmieście are connected with fall in air temperature below $-5.5^{\circ} \mathrm{C}$ and rise in pressure over $1,025 \mathrm{hPa}$.

The clusters exhibiting the highest concentration of $\mathrm{SO}_{2}$ and PM10 were also characterised by its greatest variability. In almost all of the cases, the standard deviation of the
Fig. 4 Number of days with violation of the acceptable mean daily particulate matter. (PM10) concentration $\left(50 \mu \mathrm{g} \cdot \mathrm{m}^{-3}\right)>$ years 2004/2005-2009/2010

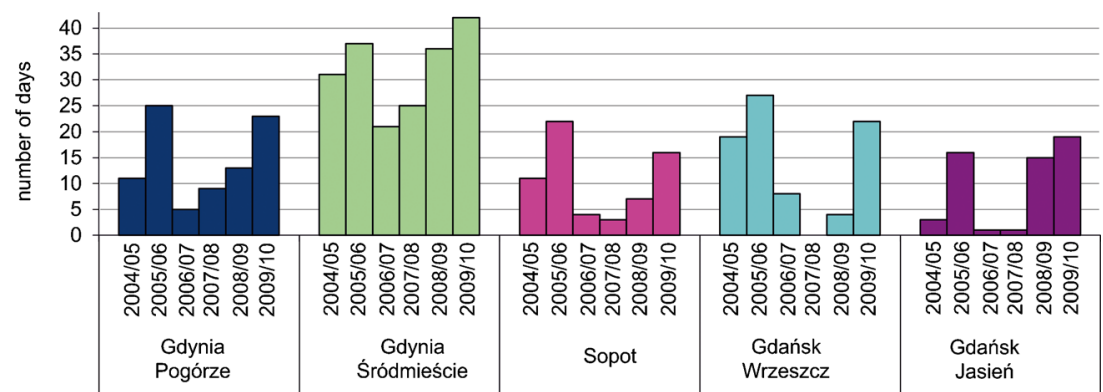


Table 1 Characteristics of sulfur dioxide and particulate matter (PM10) concentrations and meteorological factors in distinct clusters

\begin{tabular}{|c|c|c|c|c|c|c|c|c|c|c|c|c|}
\hline \multirow[t]{2}{*}{ Station } & \multirow[t]{2}{*}{ Cluster } & \multicolumn{2}{|c|}{$\mathrm{SO}_{2}\left(\mu \mathrm{g} \cdot \mathrm{m}^{-3}\right)$} & \multicolumn{2}{|c|}{$\mathrm{AT}\left({ }^{\circ} \mathrm{C}\right)$} & \multicolumn{2}{|c|}{ RH (\%) } & \multicolumn{2}{|c|}{$\mathrm{PH}(\mathrm{hPa})$} & \multicolumn{2}{|c|}{$\operatorname{PM} 10\left(\mu \mathrm{g} \cdot \mathrm{m}^{-3}\right)$} & \multirow[t]{2}{*}{ Cases $(\%)$} \\
\hline & & $\mathrm{a}$ & $\mathrm{b}$ & $\mathrm{a}$ & $\mathrm{b}$ & a & $\mathrm{b}$ & a & $\mathrm{b}$ & $\mathrm{a}$ & $\mathrm{b}$ & \\
\hline \multicolumn{13}{|l|}{ Sulfur dioxide } \\
\hline \multirow[t]{2}{*}{ Gdynia Pogórze } & 1 & 11.2 & 16.5 & -1.9 & 4.6 & 80 & 11.6 & 1,031 & 10.7 & & & 37.4 \\
\hline & 2 & 6.8 & 8.2 & 2.8 & 3.3 & 90 & 7.8 & 1,012 & 10.8 & & & 62.6 \\
\hline \multirow[t]{4}{*}{ Sopot } & 1 & 12.9 & 15.0 & -2.0 & 5.6 & 70 & 8.8 & 1,018 & 10.2 & & & 12.8 \\
\hline & 2 & 7.1 & 8.4 & 0.0 & 5.2 & 90 & 7.4 & 1,012 & 12.5 & & & 21.2 \\
\hline & 3 & 5.5 & 5.7 & 4.4 & 3.4 & 86 & 7.8 & 1,000 & 8.6 & & & 35.6 \\
\hline & 4 & 5.6 & 6.0 & 1.0 & 4.0 & 88 & 5.1 & 1,019 & 7.5 & & & 30.4 \\
\hline \multirow[t]{4}{*}{ Gdańsk Wrzeszcz } & 1 & 6.2 & 6.0 & -0.2 & 4.2 & 89 & 5.0 & 1,023 & 7.5 & & & 32.2 \\
\hline & 2 & 11.4 & 13.2 & -2.3 & 5.9 & 70 & 7.8 & 1,021 & 10.7 & & & 16.5 \\
\hline & 3 & 9.3 & 13.9 & -00.7 & 4.7 & 88 & 7.7 & 1,018 & 11.6 & & & 13.7 \\
\hline & 4 & 4.5 & 4.0 & 30.7 & 3.4 & 87 & 7.2 & 1,004 & 8.5 & & & 37.6 \\
\hline \multirow[t]{6}{*}{ Gdańsk Jasień } & 1 & 5.5 & 4.0 & 0.0 & 3.2 & 90 & 5.7 & 1,011 & 9.6 & & & 6.5 \\
\hline & 2 & 4.9 & 3.7 & 1.0 & 3.2 & 89 & 6.1 & 1,005 & 7.6 & & & 24.3 \\
\hline & 3 & 12.3 & 14.1 & -6.0 & 5.6 & 75 & 8.8 & 1,021 & 10.2 & & & 11.8 \\
\hline & 4 & 4.7 & 3.3 & -0.3 & 3.6 & 89 & 4.6 & 1,026 & 6.8 & & & 22.5 \\
\hline & 5 & 14.1 & 15.1 & -7.4 & 5.7 & 82 & 8.6 & 1,030 & 10.5 & & & 5.1 \\
\hline & 6 & 4.8 & 4.8 & 1.4 & 5.1 & 83 & 8.1 & 1,013 & 12.2 & & & 29.7 \\
\hline \multicolumn{13}{|c|}{ Particulate matter PM10 } \\
\hline \multirow[t]{2}{*}{ Gdynia Pogórze } & 1 & & & 2.8 & 3.3 & 90 & 7.8 & 1,012 & 11.0 & 28.7 & 21.6 & 63.4 \\
\hline & 2 & & & -2.0 & 4.6 & 80 & 11.6 & 1,031 & 10.8 & 35.8 & 34.3 & 36.6 \\
\hline \multirow[t]{4}{*}{ Gdynia Śródmieście } & 1 & & & -5.5 & 4.4 & 70 & 11.5 & 1,026 & 10.4 & 79.4 & 64.3 & 21.3 \\
\hline & 2 & & & 1.2 & 2.7 & 84 & 9.4 & 1,003 & 7.3 & 51.6 & 37.9 & 26.8 \\
\hline & 3 & & & 1.1 & 2.8 & 85 & 7.8 & 1,021 & 6.9 & 45.4 & 30.5 & 34.1 \\
\hline & 4 & & & 1.4 & 4.2 & 77 & 11.1 & 1,013 & 11.2 & 34.3 & 29.3 & 17.8 \\
\hline \multirow[t]{3}{*}{ Sopot } & 1 & & & -1.3 & 5.2 & 83 & 10.0 & 1,021 & 8.7 & 33.2 & 32.7 & 40.0 \\
\hline & 2 & & & 2.8 & 4.9 & 79 & 10.9 & 1,008 & 10.9 & 19.2 & 14.4 & 8.6 \\
\hline & 3 & & & 3.7 & 3.2 & 89 & 7.4 & 1,003 & 9.2 & 26.3 & 19.9 & 51.4 \\
\hline \multirow[t]{3}{*}{ Gdańsk Wrzeszcz } & 1 & & & -0.6 & 4.6 & 88 & 7.7 & 1,018 & 11.7 & 50.9 & 56.3 & 13.8 \\
\hline & 2 & & & -2.4 & 5.0 & 80 & 10.7 & 1,024 & 9.0 & 35.9 & 39.4 & 33.8 \\
\hline & 3 & & & 3.3 & 3.2 & 87 & 7.7 & 1,008 & 9.9 & 24.7 & 20.1 & 52.4 \\
\hline \multirow[t]{5}{*}{ Gdańsk Jasień } & 1 & & & -0.1 & 3.8 & 71 & 6.6 & 1,017 & 10.0 & 21.2 & 16.7 & 9.7 \\
\hline & 2 & & & -10.0 & 4.1 & 82 & 7.9 & 1,025 & 11.2 & 67.2 & 43.0 & 11.1 \\
\hline & 3 & & & 0.8 & 5.2 & 83 & 8.6 & 1,014 & 10.9 & 19.1 & 13.6 & 30.4 \\
\hline & 4 & & & 0.2 & 3.1 & 89 & 4.3 & 1,024 & 7.3 & 24.4 & 16.1 & 23.5 \\
\hline & 5 & & & 0.5 & 3.0 & 90 & 4.8 & 1,005 & 7.3 & 32.7 & 22.2 & 25.2 \\
\hline
\end{tabular}

$a$ Mean concentration, $b$ standard deviation

concentration of the two pollutants reached its highest levels which generally were contrastively high in comparison to the clusters grouping the lowest levels of concentration. In addition, the clusters with the highest and most variable concentrations were recorded for the most part in the conditions of highly varied air temperature and relative humidity, during weather marked by both small as well as high variability of pressure.
As is presented in Table 2, all clusters grouping the highest concentrations of particulate matter were characterised simultaneously by the highest share of unfavourable conditions of natural air ventilation represented by "calm" class of wind speed not more than $1 \mathrm{~m} \cdot \mathrm{s}^{-1}$. In Gdańsk Wrzeszcz, the frequency of such unfavourable conditions of dispersion in cluster 1 was approximately $95 \%$ which assuredly explains explicitly higher concentrations of PM10 particulate matter 
Table 2 Frequency (\%) of wind directions and calms (a) and concentrations of $\mathrm{SO}_{2}$ and PM10 (b) in distinct clusters

\begin{tabular}{|c|c|c|c|c|c|c|c|c|c|}
\hline \multirow[t]{2}{*}{ Station } & \multirow[t]{2}{*}{ Cluster } & \multicolumn{2}{|l|}{ Calm } & \multicolumn{2}{|l|}{ Weak } & \multicolumn{2}{|c|}{ Moderate } & \multicolumn{2}{|c|}{ Strong } \\
\hline & & $\mathrm{a}$ & $\mathrm{b}$ & $\mathrm{a}$ & $\mathrm{b}$ & $\mathrm{a}$ & $\mathrm{b}$ & $\mathrm{a}$ & $\mathrm{b}$ \\
\hline \multicolumn{10}{|l|}{ Sulfur dioxide } \\
\hline \multirow[t]{2}{*}{ Gdynia Pogórze } & 1 & 19.5 & 10.7 & 69.0 & 11.5 & 11.5 & 10.7 & $-^{\mathrm{a}}$ & ${ }^{\mathrm{a}}$ \\
\hline & 2 & 16.4 & 6.0 & 72.7 & 6.9 & 10.9 & 7.9 & $-^{\mathrm{a}}$ & ${ }^{\mathrm{a}}$ \\
\hline \multirow[t]{4}{*}{ Sopot } & 1 & $-^{\mathrm{a}}$ & $-^{\mathrm{a}}$ & 86.8 & 13.7 & 13.2 & 7.5 & $-^{\mathrm{a}}$ & ${ }^{\mathrm{a}}$ \\
\hline & 2 & 93.8 & 7.2 & $-^{\mathrm{a}}$ & $-^{\mathrm{a}}$ & 6.2 & 5.5 & $-^{\mathrm{a}}$ & $-^{\mathrm{a}}$ \\
\hline & 3 & $-^{\mathrm{a}}$ & $-^{\mathrm{a}}$ & 90.8 & 5.7 & 9.2 & 3.4 & $-^{\mathrm{a}}$ & $-^{\mathrm{a}}$ \\
\hline & 4 & $-^{\mathrm{a}}$ & $-^{\mathrm{a}}$ & 96.8 & 5.6 & 3.2 & 4.2 & $-^{\mathrm{a}}$ & $-^{\mathrm{a}}$ \\
\hline \multirow[t]{4}{*}{ Gdańsk Wrzeszcz } & 1 & $-^{\mathrm{a}}$ & $-^{\mathrm{a}}$ & 98.3 & 6.2 & 1.7 & 6.5 & $-^{\mathrm{a}}$ & $-^{\mathrm{a}}$ \\
\hline & 2 & $-^{\mathrm{a}}$ & $-^{\mathrm{a}}$ & 89.4 & 11.9 & 10.5 & 7.2 & 0.1 & 1.2 \\
\hline & 3 & 94.6 & 9.4 & $-^{\mathrm{a}}$ & $-^{\mathrm{a}}$ & 5.4 & 6.9 & $-^{\mathrm{a}}$ & $-^{\mathrm{a}}$ \\
\hline & 4 & $-^{\mathrm{a}}$ & $-^{\mathrm{a}}$ & 86.9 & 4.6 & 13.0 & 3.6 & 0.1 & 2.0 \\
\hline \multirow[t]{6}{*}{ Gdańsk Jasień } & 1 & 99.8 & 5.5 & $-^{\mathrm{a}}$ & $-^{\mathrm{a}}$ & $-^{\mathrm{a}}$ & $-^{\mathrm{a}}$ & 0.2 & 2.4 \\
\hline & 2 & $-^{\mathrm{a}}$ & $-^{\mathrm{a}}$ & 99.2 & 4.9 & $-^{\mathrm{a}}$ & $-^{\mathrm{a}}$ & 0.8 & 2.5 \\
\hline & 3 & $-{ }^{\mathrm{a}}$ & $-^{\mathrm{a}}$ & 99.3 & 12.3 & $-^{\mathrm{a}}$ & $-^{\mathrm{a}}$ & 0.7 & 3.3 \\
\hline & 4 & $-^{\mathrm{a}}$ & $-^{\mathrm{a}}$ & 99.7 & 4.7 & $-^{\mathrm{a}}$ & $-^{\mathrm{a}}$ & 0.3 & 4.9 \\
\hline & 5 & 99.0 & 14.2 & $-^{\mathrm{a}}$ & $-^{\mathrm{a}}$ & $-^{\mathrm{a}}$ & $-^{\mathrm{a}}$ & 1.0 & 6.6 \\
\hline & 6 & $-^{\mathrm{a}}$ & $-^{\mathrm{a}}$ & $-^{\mathrm{a}}$ & $-^{\mathrm{a}}$ & 97.2 & 4.9 & 2.8 & 2.6 \\
\hline \multicolumn{10}{|c|}{ Particulate matter PM10 } \\
\hline \multirow[t]{2}{*}{ GdyniaPogórze } & 1 & 16.3 & 40.0 & 72.9 & 26.6 & 10.8 & 26.1 & $-^{\mathrm{a}}$ & $-^{\mathrm{a}}$ \\
\hline & 2 & 19.8 & 45.5 & 68.4 & 34.1 & 11.7 & 29.4 & $-^{\mathrm{a}}$ & $-^{\mathrm{a}}$ \\
\hline \multirow[t]{4}{*}{ Gdynia Śródmieście } & 1 & 15.7 & 140.3 & 84.0 & 68.1 & $-^{\mathrm{a}}$ & $-^{\mathrm{a}}$ & 0.3 & 32.7 \\
\hline & 2 & 11.5 & 84.9 & 88.5 & 46.7 & $-^{\mathrm{a}}$ & $-^{\mathrm{a}}$ & $-^{\mathrm{a}}$ & $-^{\mathrm{a}}$ \\
\hline & 3 & 10.5 & 71.6 & 89.4 & 42.4 & $-^{\mathrm{a}}$ & $-^{\mathrm{a}}$ & 0.1 & 16.5 \\
\hline & 4 & 8.8 & 47.8 & $-^{\mathrm{a}}$ & & 90.2 & 33.3 & 1.0 & 29.1 \\
\hline \multirow[t]{3}{*}{ Sopot } & 1 & 21.3 & 47.3 & 78.7 & 29.4 & $-^{\mathrm{a}}$ & & $-^{\mathrm{a}}$ & $-^{\mathrm{a}}$ \\
\hline & 2 & 15.6 & 25.9 & $-^{\mathrm{a}}$ & & 84.4 & 17.9 & $-^{\mathrm{a}}$ & $-^{\mathrm{a}}$ \\
\hline & 3 & 19.6 & 38.7 & 80.4 & 23.3 & $-^{\mathrm{a}}$ & & $-^{\mathrm{a}}$ & $-^{\mathrm{a}}$ \\
\hline \multirow[t]{3}{*}{ Gdańsk Wrzeszcz } & 1 & 94.6 & 52.2 & $-^{\mathrm{a}}$ & & 5.4 & 28.6 & $-^{\mathrm{a}}$ & $-^{\mathrm{a}}$ \\
\hline & 2 & $-^{\mathrm{a}}$ & $-{ }^{\mathrm{a}}$ & 95.5 & 36.4 & 4.5 & 25.3 & $-^{\mathrm{a}}$ & $-^{\mathrm{a}}$ \\
\hline & 3 & $-^{\mathrm{a}}$ & $-^{\mathrm{a}}$ & 89.2 & 25.5 & 10.8 & 17.4 & $-^{\mathrm{a}}$ & $-^{\mathrm{a}}$ \\
\hline \multirow[t]{5}{*}{ Gdańsk Jasień } & 1 & 7.9 & 37.7 & 86.3 & 19.9 & $-^{\mathrm{a}}$ & $-^{\mathrm{a}}$ & 5.8 & 17.6 \\
\hline & 2 & 32.5 & 84.5 & 67.0 & 59.1 & $-^{\mathrm{a}}$ & $-^{\mathrm{a}}$ & 0.5 & 18.6 \\
\hline & 3 & 2.7 & 30.4 & $-^{\mathrm{a}}$ & $-^{\mathrm{a}}$ & 95.8 & 18.9 & 1.5 & 10.2 \\
\hline & 4 & 12.5 & 34.1 & 87.2 & 23.1 & $-^{\mathrm{a}}$ & $-^{\mathrm{a}}$ & 0.3 & 8.7 \\
\hline & 5 & 14.0 & 49.4 & 85.4 & 30.2 & $-^{\mathrm{a}}$ & $-^{\mathrm{a}}$ & 0.7 & 7.4 \\
\hline
\end{tabular}

${ }^{\text {a }}$ Lack of occurrence or less than three cases

recorded in the conditions of markedly higher temperature and lower pressure as compared to those belonging to cluster 2 . The comparison of mean concentrations of particulate matter recorded in individual wind speed classes indicates a markedly positive ventilation effect of this element. In all of the clusters and in all districts of Trójmiasto, the highest concentration of PM10 was recorded during "calm" class; by contrast, it was over four times lower in the conditions corresponding to "strong" class which was recorded far less frequently. Such great efficiency of anemometric conditions in particulate matter dispersion was observed in Gdynia Śródmieście and Gdańsk Jasień. In one cluster in Gdynia Śródmieście, concentrations recorded during wind speed of maximum $1 \mathrm{~m} \cdot \mathrm{s}^{-1}$ amounted to approximately $140 \mu \mathrm{g} \cdot \mathrm{m}^{-3}$, 
whereas concentrations recorded during wind speed over $8 \mathrm{~m}$. $\mathrm{s}^{-1}$ amounted to merely $33 \mu \mathrm{g} \cdot \mathrm{m}^{-3}$. The decrease in PM10 concentration was even greater in cluster 5 in Gdańsk Jasien - from approximately 49 to approximately $7 \mu \mathrm{g} \cdot \mathrm{m}^{-3}$.

Such congruence of the highest concentrations recorded at clearly increased frequency of class "calm" is not observed in respect to sulfur dioxide concentration levels. The highest concentrations of $\mathrm{SO}_{2}$ did not occur during the worst but in the not-so-favourable ventilation conditions represented by "weak" class. Additionally, in the district which exhibits the highest sulfur dioxide pollution (Gdynia Pogórze), the role of wind-driven transport heavily determined the level of concentration of the pollutant. In cluster 1, equally high concentration of $\mathrm{SO}_{2}$ was recorded both in "calm" as well as "moderate" wind class. The prevalence of the wind-driven transport was marked in cluster 2 where the greatest concentration was connected with "moderate" wind class. The wind of speed over $8 \mathrm{~m} \cdot \mathrm{s}^{-1}$ which, according to Parczewski (in KozłowskaSzczęsna et al. 1997), generates moderate turbulence, occurred with small frequency and almost exclusively in Gdańsk Jasień. The cluster in this district was marked by slightly higher share of the most favourable speed class ("strong") and smaller PM10 concentration than in clusters 1 and 3 and $\mathrm{SO}_{2}$ concentration in clusters 2, 4 and 6 (Tables 1 and 2). However, cluster 5 with a significant $1 \%$ share of hours of "strong" class was characterised by the highest $\mathrm{SO}_{2}$ concentration which can be connected with the frequency of the weakest conditions of ventilation $(99 \%)$, particularly that this cluster includes only $5 \%$ of the cases under study.

The results of the analysis, which aims to quantify the impact of weather conditions on the concentration variability of both pollutants are shown in Table 3 . The role of meteorological conditions in explaining the variability of the concentration of pollutants proved to be statistically significant in all the clusters. The complex influence of the basic elements of weather on the variability of concentrations of both pollutants proved to be comparable - the range of determination coefficients calculated for $\mathrm{SO}_{2}$ was similar to that of PM10. The smallest total determination coefficients amounted to only a few percent (for example approximately $1 \%$ in clustering 2 for $\mathrm{SO}_{2}$ in Gdynia Pogórze or $4 \%$ in clustering 1 for PM10 in Gdańsk Jasień), whereas the highest did not exceed $30 \%$. The strongest influence of atmospheric conditions was shown in respect to most clusters grouping the highest concentrations and possibly to clusters with increased concentration levels. However, the smallest total determination coefficients were usually recorded in respect to clusters grouping lower concentrations. The most explicit and contrast role of weather conditions in the explanation of the variability of $\mathrm{SO}_{2}$ and PM10 was found in Gdynia Pogórze, whereas markedly the most complex relationship between weather and concentrations of both pollutants was demonstrated for Gdańsk Jasień district.
Low concentrations of approximate values in clusters 2, 4 and 6 in this district (from 4.7 to $4.9 \mu \mathrm{g} \cdot \mathrm{m}^{-3}$; Table 1) occurred at distinctively divergent influence of atmospheric conditions and the strongest and the most complex influence of weather $\left(R^{2}\right)$ was evident in clustering 3 in which the average $\mathrm{SO}_{2}$ concentration was smaller than in clustering 5 .

Data in Table 3 shows that the sets of meteorological elements which substantially describe the concentrations of the analysed pollutants for the most part comprise three to four elements, and only one element of weather has a significant influence only in some clusterings - those referring to $\mathrm{SO}_{2}$. The sets including all the analysed meteorological elements in most cases described the variability of the highest concentration of both pollutants. The values of the partial determination coefficient $\left(r^{2}\right)$ indicate that in six of the analysed winter seasons, the most frequent basic meteorological element which explains the variability of the hourly sulfur dioxide concentration was air temperature. Better statistic description of the fall in $\mathrm{SO}_{2}$ concentration in the conditions of weaker anticyclonic weather was brought by relative humidity only in the first clusterings, in Gdynia Pogórze and Gdańsk Jasień.

The principal meteorological elements which explain the values and variability of particulate matter PM10 concentration in the period 2004/2005-2009/2010 were air temperature and wind speed. Markedly stronger influence of thermal conditions on the highest average concentration of particulate matter in the distinguished clusterings was recorded in Gdynia Pogórze, Sopot and Gdańsk Wrzeszcz. As has already been presented in Table 2, the wind speed which was several times higher was observed in Gdynia Śródmieście and Gdańsk Jasień in clusters marked by more frequent conditions of weaker ventilation, close to "calm" class. The predominant influence of air temperature on $\mathrm{SO}_{2}$ concentration and equal influence of temperature and wind speed on PM10 particulate matter was observed in Poland during freezing winter of 2005/2006 (Czarnecka and Nidzgorska-Lencewicz 2011).

The relationship between sulfur dioxide, particulate matter and air temperature, and wind speed was characterised by almost exclusively negative directional coefficients which means that their increase brought decrease in both pollutants. The negative correlation of sulfur dioxide concentration and particulate matter PM10 with air temperature is evident as it is a consequence of the fact that this element reflects the intensity of the heating processes which in turn is connected with the amount of emission. Data in Table 3 reveal that wind was an effective air ventilation factor, contributing primarily to a decrease in particulate matter concentration and generally also sulfur dioxide concentration. Statistically significant negative effect of wind speed was found only in Gdynia Pogórze (cluster 2). This primary role of wind in urban ventilation was also postulated by Pires et al. (2008), Unal et al. (2011), Zabalza et al.(2007) and Kukkonen et al. (2005), on the other hand, obtained different directional coefficients for the 
Table 3 Coefficients of total $\left(R^{2}\right)$ and partial determination $\left(r^{2}\right)$ in percentage for the relationships between sulfur dioxide and particulate matter (PM10) concentrations and meteorological elements in distinct clusters

\begin{tabular}{|c|c|c|c|c|c|c|}
\hline \multirow[t]{2}{*}{ Station } & \multirow[t]{2}{*}{ Cluster } & \multirow[t]{2}{*}{$R^{2}$} & \multicolumn{4}{|l|}{$r^{2}$} \\
\hline & & & $\mathrm{AT}$ & $\mathrm{RH}$ & $\mathrm{PH}$ & WS \\
\hline \multicolumn{7}{|l|}{ Sulfur dioxide } \\
\hline Gdynia & 1 & 16.2 & 6.0 & 10.9 & 3.1 & 0.2 \\
\hline Pogórze & 2 & 1.2 & 0.3 & 0.7 & $-{ }^{\mathrm{a}}$ & 0.2 \\
\hline \multirow[t]{4}{*}{ Sopot } & 1 & 23.7 & 14.5 & 0.9 & 1.7 & 0.9 \\
\hline & 2 & 11.0 & 9.0 & $-{ }^{\mathrm{a}}$ & 0.4 & 0.3 \\
\hline & 3 & 16.5 & 16.5 & $-^{\mathrm{a}}$ & $-^{\mathrm{a}}$ & $-^{\mathrm{a}}$ \\
\hline & 4 & 10.5 & 10.3 & $-{ }^{\mathrm{a}}$ & $-^{\mathrm{a}}$ & 0.2 \\
\hline \multirow[t]{4}{*}{ Gdańsk Wrzeszcz } & 1 & 23.3 & 23.2 & 0.4 & $-^{\mathrm{a}}$ & $-^{\mathrm{a}}$ \\
\hline & 2 & 25.7 & 15.3 & 2.1 & 2.8 & 0.8 \\
\hline & 3 & 20.2 & 12.8 & 3.5 & $-^{\mathrm{a}}$ & 0.7 \\
\hline & 4 & 17.2 & 14.8 & 2.2 & 0.1 & 0.4 \\
\hline \multirow[t]{6}{*}{ Gdańsk Jasień } & 1 & 12.3 & 1.4 & 10.3 & $-^{\mathrm{a}}$ & $-^{\mathrm{a}}$ \\
\hline & 2 & 4.4 & 4.4 & $-{ }^{\mathrm{a}}$ & $-^{\mathrm{a}}$ & $-^{\mathrm{a}}$ \\
\hline & 3 & 24.4 & 13.5 & 1.2 & 3.2 & 1.1 \\
\hline & 4 & 4.1 & 2.7 & 0.4 & $-^{\mathrm{a}}$ & 1.0 \\
\hline & 5 & 15.5 & 15.5 & $-^{\mathrm{a}}$ & $-^{\mathrm{a}}$ & $-^{\mathrm{a}}$ \\
\hline & 6 & 14.8 & 13.9 & 0.9 & 1.0 & 0.3 \\
\hline \multicolumn{7}{|c|}{ Particulate matter PM10 } \\
\hline Gdynia & 1 & 8.6 & 5.6 & $-{ }^{\mathrm{a}}$ & $-^{\mathrm{a}}$ & 2.0 \\
\hline Pogórze & 2 & 17.8 & 15.0 & 1.6 & 1.0 & 3.8 \\
\hline \multirow[t]{2}{*}{ Gdynia } & 1 & 28.2 & 4.5 & 1.7 & 0.8 & 15.1 \\
\hline & 2 & 24.4 & 5.6 & 2.0 & 0.8 & 13.5 \\
\hline \multirow[t]{2}{*}{ Śródmieście } & 3 & 14.9 & 0.5 & 0.2 & 0.2 & 12.3 \\
\hline & 4 & 12.9 & 11.4 & 1.0 & $-^{\mathrm{a}}$ & 1.6 \\
\hline \multirow[t]{3}{*}{ Sopot } & 1 & 25.4 & 19.0 & 0.2 & 1.2 & 4.2 \\
\hline & 2 & 9.3 & 5.7 & 1.0 & $-^{\mathrm{a}}$ & 2.2 \\
\hline & 3 & 19.6 & 5.1 & 0.1 & $-^{\mathrm{a}}$ & 9.4 \\
\hline Gdańsk & 1 & 20.2 & 18.5 & 0.9 & $-^{\mathrm{a}}$ & 2.4 \\
\hline \multirow[t]{2}{*}{ Wrzeszcz } & 2 & 21.5 & 20.8 & 0.2 & 0.6 & 1.3 \\
\hline & 3 & 12.4 & 7.8 & 0.3 & $-^{\mathrm{a}}$ & 0.4 \\
\hline \multirow[t]{5}{*}{ Gdańsk Jasień } & 1 & 4.0 & 0.5 & 0.7 & $-^{\mathrm{a}}$ & 1.7 \\
\hline & 2 & 13.9 & 0.9 & 2.3 & $-^{\mathrm{a}}$ & 12.2 \\
\hline & 3 & 12.0 & 9.3 & 0.2 & 0.7 & 3.0 \\
\hline & 4 & 10.6 & 0.7 & 0.3 & $-^{\mathrm{a}}$ & 9.3 \\
\hline & 5 & 16.2 & 3.6 & 1.3 & $-^{\mathrm{a}}$ & 9.2 \\
\hline
\end{tabular}

Italicized value indicates a positive relationship

${ }^{\text {a }}$ Non significant at $\alpha=0.05$

relationship between concentrations and wind speed during episodes of elevated PM10.

The influence of pressure on concentrations of both pollutants was incomparably smaller, yet its increase for the most part resulted in the increase in the concentration of pollutants. Opposite directions describe the relationship of sulfur dioxide and particulate matter with relative humidity. Along with the increase of relative humidity, sulfur dioxide concentration decreased, yet the influence of this element on particulate matter concentration was ambiguous in terms of the direction of the influence though it was statistically significant in almost all clusters. The relationships, explicit in terms of direction, of sulfur dioxide concentrations with air relative humidity are related to the high reactivity of the chemical, especially as far 
as the processes of catalytic oxidation is concerned, which produces sulfuric acid and sulfates; this is particularly intensive at humidity levels close to saturation, such as during fog (Freiberg 1974). The processes of intensified chemical bonding of sulfur dioxide under high relative humidity may explain the decrease in its concentration in the air, but the complexity of the processes is also due to many other factors, such as temperature, $\mathrm{pH}$ or the atmosphere balance. Negative correlations of $\mathrm{SO}_{2}$ concentrations, but also those of PM10, with a relative humidity throughout the year, were demonstrated by Freitas et al. (2010) and by Pires et al. (2008), and sulfur dioxide concentrations alone in the winter months, from December to February, were shown by Cuhudaroglu and Demirci (1997). On the other hand, the results reported by Elminir (2005) for Egypt indicate significantly higher annual average concentrations of both pollutants (particulate matter even twice) under high, more than $80 \%$, relative humidity. However, already a month-by-month analysis reveals that the positive correlation of PM10 concentration on the relative humidity is also visible in all the months from December to February, whereas for sulfur dioxide, the sign of the correlation in January and February was negative.

Observing the fact that the amount of concentration of pollutants is the result of exogenous emission, both from distant as well as local sources from neighbouring districts, the analysis of anemometric conditions for clusterings grouping on average the highest concentrations of the analysed pollutants. The results of the analysis are presented in Fig. 5 and comprise mean sulfur dioxide concentration and particulate matter according to the direction of wind with speed at least $1 \mathrm{~m} \cdot \mathrm{s}^{-1}$ (wind of three classes of Knoch's classification-weak, moderate and strong) and the concentrations which occur in the worst conditions of natural air ventilation that is "calm" class. The highest average sulfur dioxide concentration was registered for the most part with SE or S direction of wind and only in Gdańsk Wrzeszcz with E direction. Only in Jasien district was the highest concentration of particulate matter recorded in the conditions of circulation from the west quadrant (SW-W-NW), particularly at W wind. In the most polluted with particulate matter PM10 district of the agglomeration, Gdynia Śródmieście, equally high concentration of pollutants (approximately $80 \mu \mathrm{g} \cdot \mathrm{m}^{-3}$ ) as with SE wind occurred during $\mathrm{S}$ wind, yet relatively high concentrations were connected with SW, W and $\mathrm{E}$ winds.

The influence of particularly unfavourable conditions of ventilation on air quality was recorded in Gdynia Śródmieście and Gdańsk Jasień. As far as in Gdynia Śródmieście, the highest average hourly concentration of particulate matter PM10 in cluster 1 recorded at different wind speed and directions amounted to approximately $79 \mu \mathrm{g} \cdot \mathrm{m}^{-3}$ (Table 1 ), the hourly concentration registered in this cluster in the conditions classified as belonging to "calm" class reached a mean value of $140 \mu \mathrm{g} \cdot \mathrm{m}^{-3}$. In Gdańsk Jasien, the unfavourable conditions of natural air ventilation above all contributed to the increase of $\mathrm{SO}_{2}$ concentration which was twice as high as with SE wind at speed over $1 \mathrm{~m} \cdot \mathrm{s}^{-1}$ and PM10 concentrations in the "calm" conditions were the highest.

Although the decisive factor for air quality during the winter season is mainly increased and often even overnormative concentration of particulate matter, according to CAQI index in the winter period of 2004/2005-2009/2010 aerosanitary conditions in the most part of Tricity belonged to "very low" class with over $50 \%$ frequency (Fig. 6). Extremely unfavourable air quality as reflected by the values of the index (more than $180 \mu \mathrm{g} \cdot \mathrm{m}^{-3}$ that is "very high") regarded few cases which were registered almost exclusively in Gdynia Śródmieście and Gdańsk Wrzeszcz. Gdynia Śródmieście
Fig. 5 Winds directions causing the greatest risk of occurrence of the highest average hourly concentrations of sulfur dioxide and particulate matter during calendar winters (December-February). Years 2004/2005-2009/2010
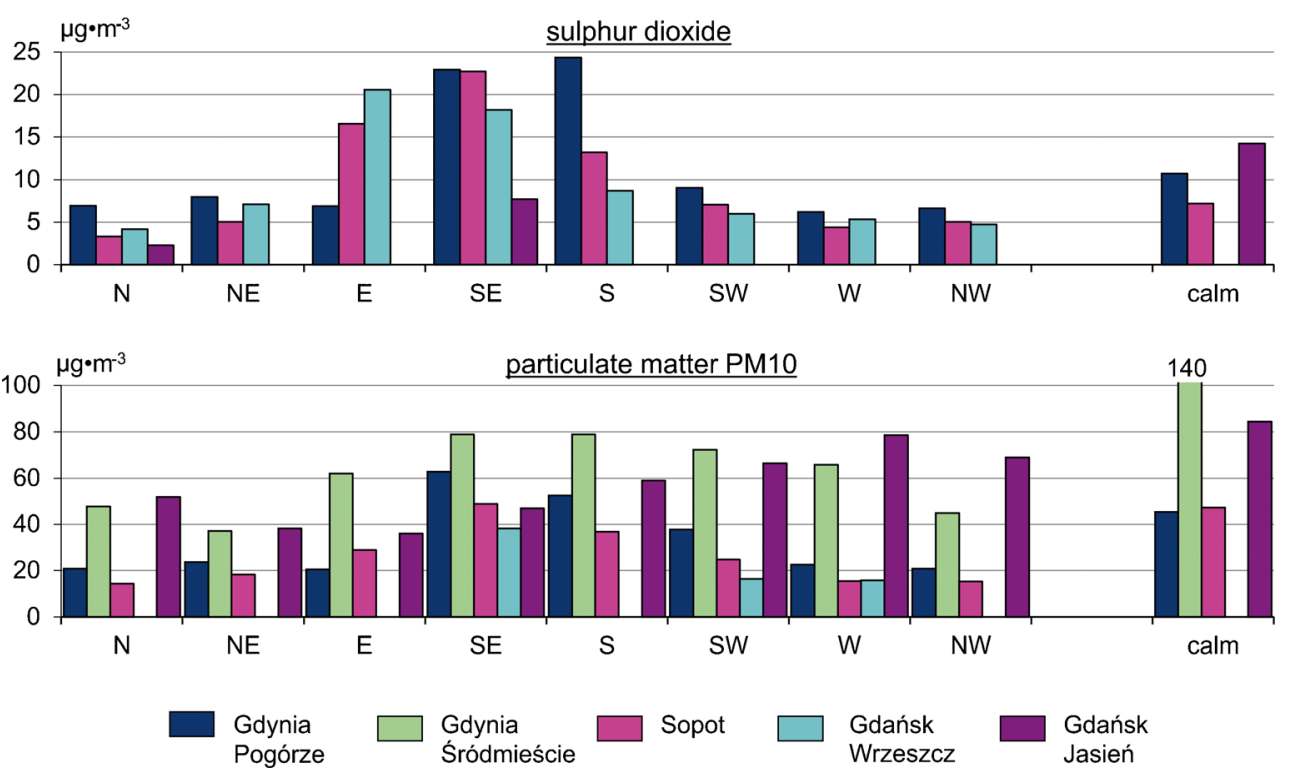
was the district most polluted with particulate matter and the "very low" class was the least frequent (30\%) as compared to other districts and the "high" class was the most frequent (10\%).

As far as "very low" air quality class dominates in the average winter conditions, the share of particular classes of the CAQI index undergoes pronounced changes (Fig. 6) in the conditions of overnormative daily concentrations of particulate matter PM10. Most of all, the share of conditions classified as "very low" falls to even below $5 \%$, whereas the share of "medium" class increases approximately five times and constitutes $40-50 \%$ of cases of daily standard being exceeded. Deterioration of air quality reflects the several times higher share of high class as compared to average conditions. The joint share of the two classes of the worst air quality, "high" and "very high", ranged from approximately $20 \%$ in Gdynia Pogórze to approximately $32 \%$ in Gdańsk Wrzeszcz, whereas in average conditions it did not exceed $10 \%$ (except for Gdynia Śródmieście district). The smallest difference between the average and extreme conditions regard the share of days classified as belonging to low class.
Fig. 6 Frequency (\%) of occurrence of the individual classes of CAQI index: during calendar winter (December-February) and in the days with the excess of the daily PM10 standard. Years 2004/ 2005-2009/2010

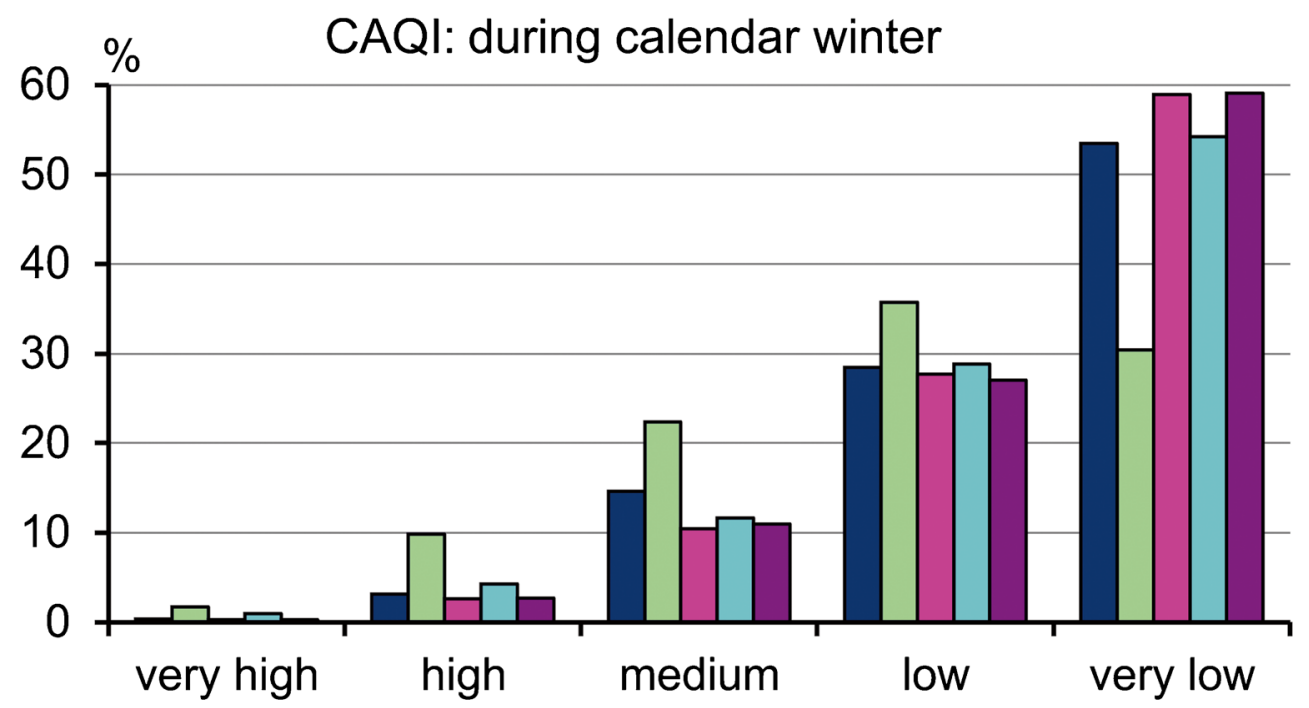

CAQI: in the days with the excess of daily

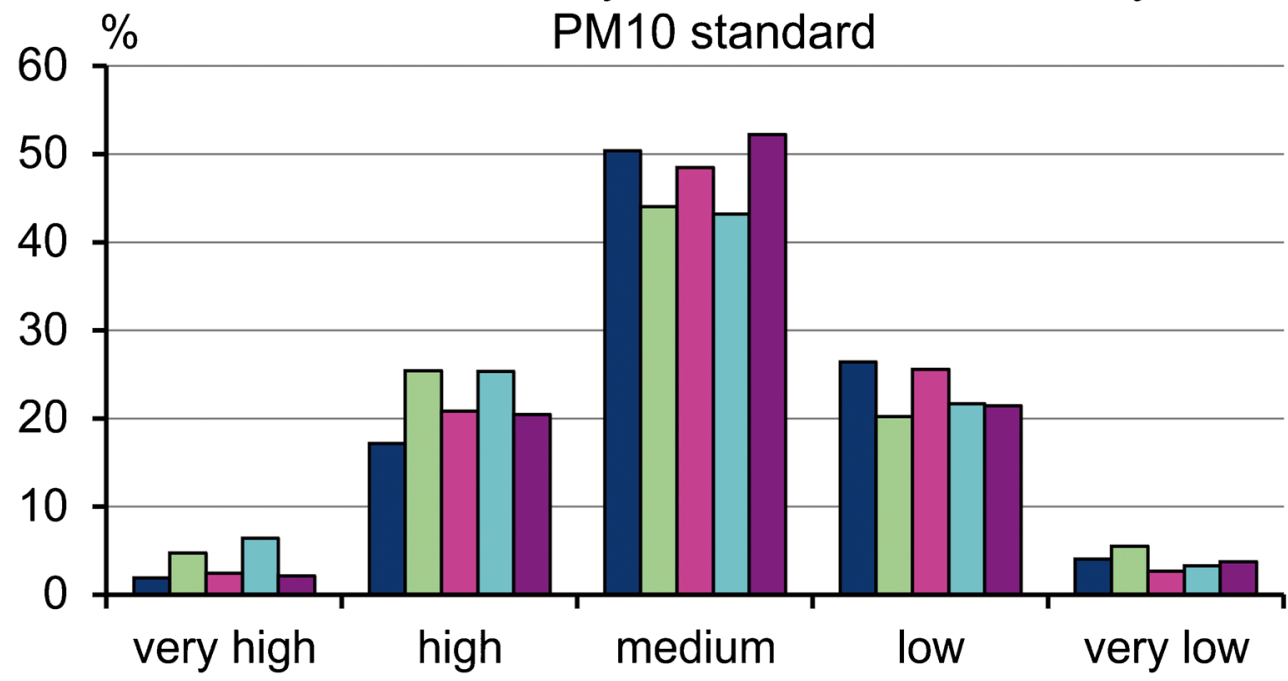

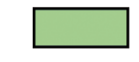

Gdynia

\section{Gdynia Sopot} Śródmieście
Gdańsk Wrzeszcz
Gdańsk Jasień 
$[\mathrm{m}] \quad\left[\mu \mathrm{g} \cdot \mathrm{m}^{-3}\right]$

$\left.\begin{array}{r}3500 \\ 3000 \\ 2500 \\ 2000 \\ 1500 \\ 1000 \\ 500 \\ 0\end{array}\right]$

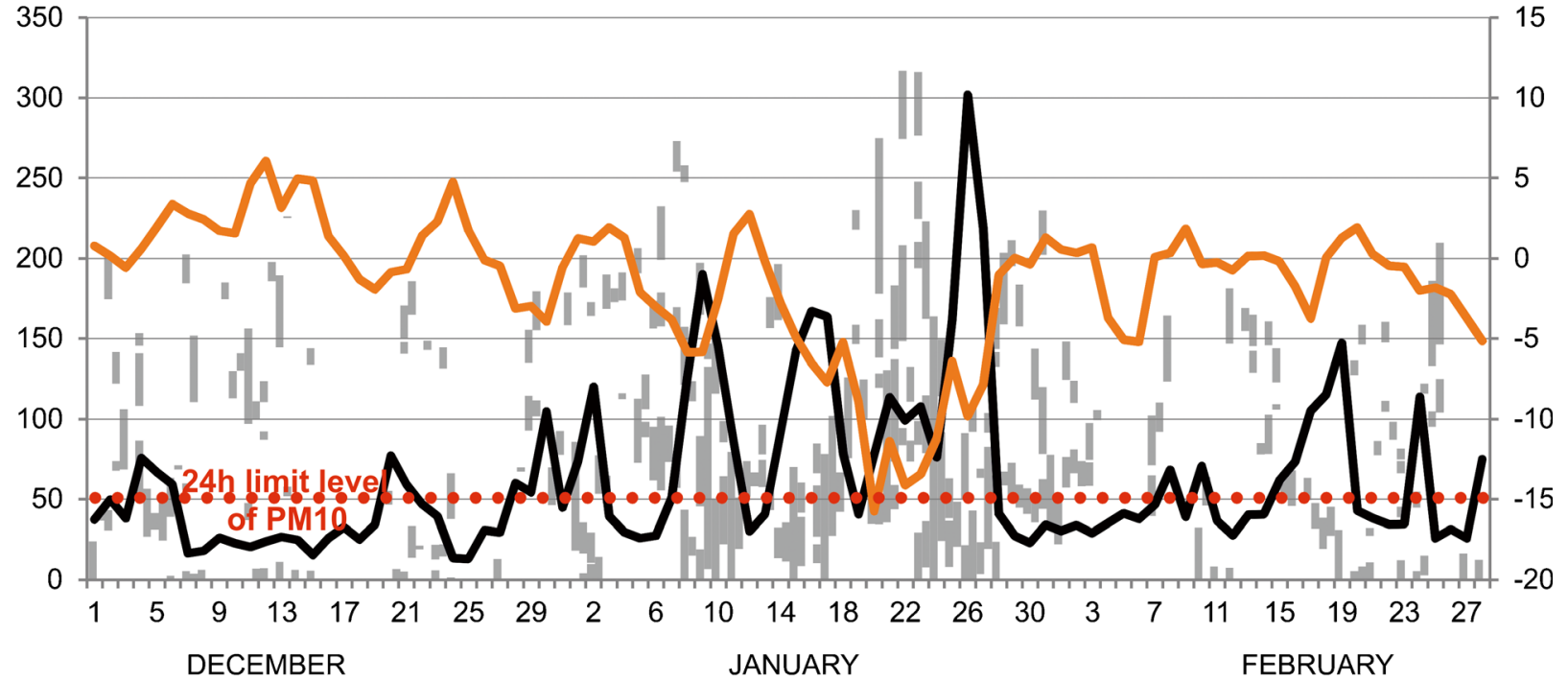

DECEMBER

\section{air temperature}

PM10

\section{thermal inversion}

Fig. 7 Distribution of the mean daily concentration of particulate matter PM10 in Gdynia Śródmieście in relation to the course of air temperature and thermal inversion, winter 2005/2006

As has been presented before, the mean daily concentrations of PM10 were exceeded and registered in Tricity agglomeration in each of the winter season in the period 2004/2005-2009/2010. In Gdynia Śródmieście, the excess of daily standards reached $35 \%$ whereas in other districts it ranged from 10 to $15 \%$ of the calendar winter. The analysis of the results of aerologic surveys shows that in Gdynia Śródmieście $67 \%$ of all cases in which the daily standards of PM1 0 concentration were exceeded in the years 2004/2005 through 2009/2010 were recorded during night (00 UTC) or daily (12 UTC) lower or upper inversions of temperature. In the winters of 2005/2006 and 2007/2008, the percentage of daily standards being exceeded in the conditions of inversion was 86 and $88 \%$, respectively. The course of mean daily concentration of particulate matter PM10 with the highest number of the excess of the standard, illustrates the influence of thermal inversions as well as air temperature on the variability of the particulate matter concentration (Fig. 7). In the winter of 2005/2006, the excess of the standard in Gdynia Śródmieście was recorded most of all in January which was marked by the highest frequency of thermal inversions, upper inversions. A sudden increase in particulate matter PM10 concentration on January 9, 16 and particularly 26, were connected with both marked decrease in temperature and 24-h inversions. The increase in concentration of pollutants on January 9 was simultaneous with the fall in temperature and the occurrence of upper and lower inversion layers. The maximum daily concentration of particulate matter on January 26 which reached $301.8 \mu \mathrm{g} \cdot \mathrm{m}^{-3}$ was recorded after the period of the greatest freezing cold and was probably the result of the
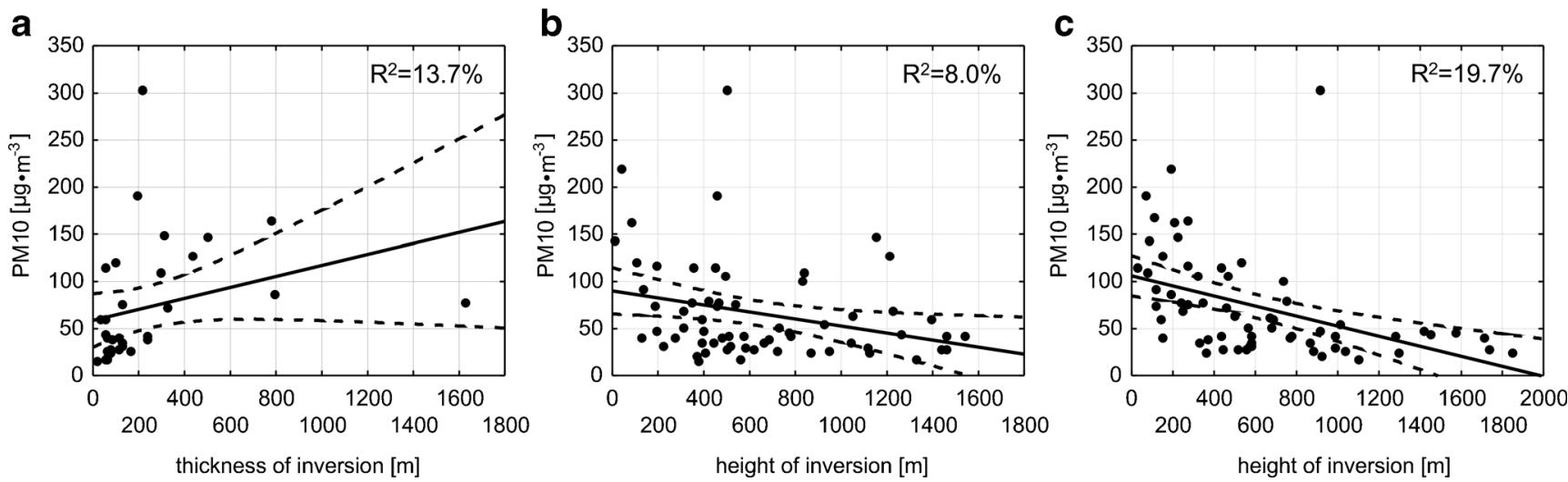

Fig. 8 The relationship between the mean daily concentration of particulate matter PM10 and the thickness of lower inversions occurring during 24-hour period (a) and the height of the base of upper inversions at 00 (b) and 12 (c) UTCI time 
accumulation of pollution in the conditions of extremely limited vertical air exchange connected with previously occurring upper inversion layers from approximately 350 to $3,100 \mathrm{~m}$ and the lower $24-\mathrm{h}$ inversion on the day of the extreme concentration of pollutants. The regression analysis indicates the statistically significant influence of inversion layers on the variability of particulate matter PM10 concentration in the winter season of $2005 / 2006$. The role of the layers hindering dispersion depended on the range of lower (ground level) inversion layers and on the hight of the base of upper inversion (elevated) as is presented in Fig. 8. The increase in thickness of lower inversions (day and night-time jointly) which occurred less frequently than upper brought a statistically significant increase of particulate matter concentration - determination coefficient amounted to approximately $14 \%$. As far as direction is concerned, the opposite relationship of concentration levels of particulate matter PM10 was found regarding upper inversions. The hight of the lower inversion base shaped the thickness of the layer of turbulent mixing and consequently the conditions of diffusion of the pollutants at the ground-level layer of air. In most cases, the upper inversion layers occurred during a 24-h period and had a significant influence on the concentration of particulate matter at night as well as daytime. However, higher location of the base of inversion contributed to a greater degree to the decrease in particulate matter PM10 concentration during daytime $\left(R^{2}\right.$ approximately $\left.20 \%\right)$ and twice less at night $\left(R^{2}=\right.$ $8 \%$ ). This corresponds with the results obtained by Knozowa (2008) regarding not only particulate matter but also $\mathrm{SO}_{2}, \mathrm{CO}$ and NOx. Multiple regression analysis indicated that in the winter of 2005/2006, the upper inversions (both night as well as day) in connection with air temperature accounted for $40 \%$ of the variability of particulate matter PM10 concentration (Table 4). In both times of day, their share expressed by partial determination coefficient was similar and markedly smaller than that of air temperature. The models depicting the variability of particulate matter and sulfur dioxide concentration levels in average conditions (developed on the basis of a 9year long series of months October-March 1990-1999 by İçağa and Sabah (2009)) also presented smaller influence of inversion in comparison with air temperature.

Table 4 Coefficients of total $\left(R^{2}\right)$ and partial determination $\left(r^{2}\right)$ in percent for the relationships between particulate matter (PM10) concentrations and thermal inversion (TI) and air temperature (AT) in Gdynia Sródmieście, winter 2005/2006

\begin{tabular}{lllll}
\hline Time & No. & $R^{2}$ & \multicolumn{2}{c}{$r^{2}$} \\
\cline { 3 - 5 } UTC & & & TI & AT \\
\hline 00 & 60 & 40.1 & 9.4 & 35.8 \\
12 & 60 & 39.8 & 9.7 & 25.1 \\
\hline
\end{tabular}

The attempt to evaluate the influence of atmosphere stratification on the dispersion of pollution with particulates was based on the results of aerologic surveys conducted at the open field in a standard meteorological station. However, in the conditions of urban development, the exchange of heat flux in the ground-level layer of air is strongly modified by physical and geometric features of the substrate as well as by the emission of artificial heat (Kuznetsova et al. 2008). Great roughness of the urban substrate which contributes to the development of the mechanic turbulence can significantly distort the formation of inversion layers. Topography of the area and its cover influence the intensity, reach and the character of inversions as well as its spatial variability (Drzeniecka-Osiadacz and Netzel 2010a; Wallace et al. 2010). Therefore, the results obtained substantiate the significant role of the structure of the thermal boundary layer of atmosphere in the shaping of the amount of concentration of pollutants in the conditions of frosty winter, yet they do not take into consideration specific features of the thermal structure of the urban boundary layer of Tricity agglomeration.

\section{Conclusions}

During the calendar winter (December-February), the worst average aerosanitary conditions of air occur in the northern part of Tricity which, in terms of administration, belongs to Gdynia, which the highest pollution by sulfur dioxide occurs in Pogórze district and the highest pollution by particulate matter PM10 in Śródmieście district, neighbouring the port area. As far as concentration levels of sulfur dioxide does not exceed the current standards, the overnormative daily concentration of particulate matter PM10 is recorded in all districts each winter in Gdynia Śródmieście $35 \%$ of days on average. Regardless of this fact, the average aerosanitary conditions of air assessed with the use of CAQI index are classified in most days of the calendar winter (December-February) as belonging to the best quality class "very low", and in the conditions of overnormative concentration, the "medium" class tends to dominate. The worst class of air quality "very high" does not pertain to even $10 \%$ of the standards being exceeded.

The increased concentrations of both pollutants are usually recorded in the conditions of the fall in temperature below $-5.5^{\circ} \mathrm{C}$, pressure over $1,020 \mathrm{hPa}$, and wind speed below $1 \mathrm{~m}$. $\mathrm{s}^{-1}$ usually SE and S. Meteorological conditions are equally strong factors in determining sulfur dioxide and particulate matter concentrations, and the main element which contributes to the increase of their concentrations is air temperature. Additionally, wind speed influences the amount of particulate matter concentration; in Gdynia Sródmieście, it is the main factor in the improvement of air quality.

Thermal conditions which express the amount of concentration of pollutants caused by the increase in intensity of the 
heating processes were the critical factors in the most frequent, overnormative daily concentrations of particulate matter in the winter of 2005/2006 in Śródmieście district, yet inversion layers, both upper as well as lower, occurring in almost all days in January 2006, also had a significant influence. The increase in the thickness of lower inversions resulted in a statistically significant increase in particulate matter concentration, and the higher depth of the basis of upper inversions particularly during daytime contributed to the decrease in the concentration of pollutants. Air temperature and the depth of the base of the lowest-occurring upper inversions accounted for approximately $40 \%$ of the variability of the overnormative concentration of particulate matter PM10 in the winter of 2005/2006

Open Access This article is distributed under the terms of the Creative Commons Attribution License which permits any use, distribution, and reproduction in any medium, provided the original author(s) and the source are credited. The authors would like to thank ARMAAG for making the data accessible.

\section{References}

Borkowski T, Tarnapowicz D, Nicewicz G (2012) Ships mooring in the port as a threat to our natural environment (in Polish). Manag Syst Prod Eng 2(6):22-27

Brunekreef B, Holgate ST (2002) Air pollution and health. Lancet 360(9341):1233-1242

Cheng CS, Campbell M, Li Q, Li G, Auld H, Day N, Pengelly D, Gingrich S, Yap D (2007) A synoptic climatological approach to assess climatic impact on air quality in south-central Canada. Part I: Historical analysis. Water, Air, Soil Pollut 182:131-148. doi:10. 1007/s11270-006-9327-3

Commission to the Council and the European Parliament (2005) Communication from the Commission to the Council and the European Parliament. Thematic strategy on air pollution Brussels, 21.9

Cuhudaroglu B, Demirci E (1997) Influence of some meteorological factors on air pollution in Trabzon city. Energy Build 25:179-184

Czarnecka M, Nidzgorska-Lencewicz J (2010) The influence of precipitation conditions on the concentration of suspended particulates PM10. Meteorology and Climatology Research, red. J Leśny Acta Agrophysica Rozprawy i Monografie nr 184:132-147

Czarnecka M, Nidzgorska-Lencewicz J (2011) Impact of weather conditions on winter and summer air quality. Int Agrophys 25(1):7-12, ISSN 0236-8722

Demuzere M, Trigo RM, Vila-Guerau de Arellano J, van Lipzig NPM (2009) The impact of weather and atmospheric circulation on O3 and PM10 levels at a rural mid-latitude site. Atmos Chem Phys 9: 2695-2714

Dominici F, Peng RD, Bell ML, Pham L, McDermott A, Zeger SL et al (2006) Fine particulate air pollution and hospital admission for cardiovascular and respiratory diseases. JAMA 295(10):1127-1134

Drzeniecka-Osiadacz A, Netzel P (2010a) Assessment of spatial variability of the inversion layer depth over Wroclaw city on a base of acoustic sounding [in Polish). Proc ECOpole 4(1):127-131

Drzeniecka-Osiadacz A, Netzel P (2010b) Wpływ warunków meteorologicznych oraz cyrkulacji atmosferycznej na stężenie PM10 we Wrocławiu (in Polish). Proc ECOpole 4(2):343-349
Elminir HK (2005) Dependence of urban air pollutants on meteorology. Sci Total Environ 350:225-237

European Environment Agency (2012) Air quality in Europe. Report 2012. No 4

Freiberg J (1974) Effects of relative humidity and temperature on ironcatalyzed oxidation of sulfur dioxide in atmospheric aerosols. Environ Sci Technol 8(8):731-734. doi:10.1021/es60093a004

Freitas MC, Pacheco AMG, Verburg TG, Wolterbeek HT (2010) Effect of particulate matter, atmospheric gases, temperature, and humidity on respiratory and circulatory diseases' trends in Lisbon. Portugal Environ Monit Assess 162:113-121. doi:10.1007/s10661-009-0780-5

Gerstengarbe F-W, Werner PC (1997) A method to estimate the statistical confidence of cluster separation. Theor Appl Climatol 57:103-110

Giorgi F, Meleux F (2007) Modelling the regional effects of climate change on air quality. C R Geosci 339:721-733

Główny Inspektorat Ochrony Środowiska (2010) Raport o stanie środowiska w Polsce, 2008. Biblioteka Monitoringu Środowiska (in Polish). Warszawa

Godłowska J, Tomaszewska AM, Hajto M, (2008) Relations between concentrations of air pollution in Cracow and conditions in the urban boundary layer qualified on the basis of sodar data (in Polish). Kłysik K., Wibig J., Fortuniak K. (eds.) - Klimat i bioklimat miast Wydawnictwo Uniwersytetu Łódzkiego, Katedra Meteorologii i Klimatologii UŁ Łódź, 455-465

Greene JS, Kalkstein LS, Ye H, Smoyer K (1999) Relationships between synoptic climatology and atmospheric pollution at 4 US cities. Theor Appl Climatol 62:163-174

Grivas G, Chaloulakou A, Samara C, Spyrellis N (2004) Spatial and temporal variation of PM10 mass concentrations within the greater area of Athens, Greece. Water, Air, Soil Pollut 158:357-371

Huszar P, Juda-Rezler K, Halenka T, Chervenkov H, Syrakov D, Krüger BC, Zanis P, Melas D, Katragkou E, Reizer M, Trapp W, Belda M (2011) Effects of climate change on ozone and particulate matter over Central and Eastern Europe. Clim Reas 50:51-68. doi:10.3354/cr01036

İçağa Y, Sabah E (2009) Statistical analysis of air pollutants and meteorological parameters in Afyon, Turkey. Environ Model Asses 14: 259-266. doi:10.1007/s10666-008-9139-5

Jacob DJ, Winner DA (2009) Effect of climate change on air quality. Atmos Environ 43:51-63

Kappos AD, Bruckmann P, Eikmann T, Englert N, Heinrich U, Hoppe P, Koch E, Krause GHM, Kreyling WG, Rauchfuss K, Rombout P, Schulz-Klemp V, Thiel WR, Wichmann HE (2004) Health effects of particles in ambient air. Int J Hyg Environ Health 207(4):399-407

Kassomenos PA, Sindosi OA, Lolis CJ, Chaloulakou A (2003) On the relation between seasonal synoptic circulation types and spatial air quality characteristics in Athens, Greece. J AirWaste Manag Assoc 53(3):309-324. doi:10.1080/10473289.2003.10466154

Knozová G (2008) Temperature inversions at Prague-Libuš aerological stadion (1975-2006) (in Polish). Kłysik K., Wibig J., Fortuniak K. (eds.) - Klimat i bioklimat miast, Wydawnictwo Uniwersytetu Łódzkiego, Katedra Meteorologii i Klimatologii UŁ Łódź, 65-80

Kozłowska-Szczęsna T, Błażejczyk K, Krawczyk B (1997). Human bioclimatology. Methods and aplications (in Polish). Polish Academy of Sciences, Institute of Geography and Spatial Organization, Monographies 1, Warsaw, 200

Kukkonen J, Pohjola M, Sokhi RS, Luhana L, Kitwiroon N, Fragkou L, Rantamäki M, Berge E, Ødegaard V, Slørdal LH, Denby B, Finardi S (2005) Analysis and evaluation of selected local-scale PM10 air pollution episodes in four European cities: Helsinki, London, Milan and Oslo. Atmos Environ 39:2759-2773

Kuznetsova IN, Nakhaeva MI, Shalygina IY, Lezina EA (2008) Meteorological prerequisites of formation of severe wintertime air pollution episodes in Moscow. Russ Meteorol Hydrol 33(3):167-174

Lazaridis M (2011) First principles of meteorology and air pollution. Springer, New York, p 362 
Lewińska J (2000) Klimat miasta. Zasoby, zagrożenia, kształtowanie (Climate of a town: resources, hazards, modifications) (in Polish). Instytut Przestrzennej i Komunalnej, Kraków, Poland, p 151

Malek E, Davis T, Martin RS, Silva PJ (2006) Meteorological and environmental aspects of one of the worst national air pollution episodes (January, 2004) in Logan, Cache Valley, Utah. USA Atmos Res 79:108-122

Medina S, Plasencia A, Ballester F, Mucke HG, Schwartz J (2004) Apheis: public health impact of PM10 in 19 European cities. J Epidem Comm Health 58:831-836

Mira-Salama D, Grüning C, Jensen NR, Cavalli P, Putaud JP, Larsen BR, Raes F, Coe H (2008) Source attribution of urban smog episodes caused by coal combustion. Atmos Res 88:294-304. doi:10.1016/j. atmosres.2007.11.025

Nilsson LJ, Pisarek M, Buriak J, Oniszk-Poplawska A, Bucko P, Ericsson K, Jaworski L (2006) Energy policy and the role of bioenergy in Poland. Energy Policy 34:2263-2278

Ocak S, Turalioglu FS (2010) Relationship between air pollutants and some meteorological parameters in Erzurum, Turkey. Dincer et al. (eds.), Global Warming, Green Energy and Technology, 485-499. DOI 10.1007/978-1-4419-1017-2 31

Olofson KFG, Andersson PU, Hallquist M, Ljungström E, Tang L, Chen D, Pettersson JBC (2009) Urban aerosol evolution and particle formation during wintertime temperature inversions. Atmos Environ 43(2):340-346. doi:10.1016/j.atmosenv.2008.09.080

Państwowy Monitoring Środowiska (PMŚ), Inspekcja Ochrony Środowiska (2011) Ocena jakości powietrza w strefach w Polsce za rok 2010. Warszawa (in Polish)

Pires JCM, Martins FG, Sousa SIV, Alvim-Ferraz MCM, Pereira MC (2008) Prediction of the daily mean PM10 concentrations using linear models. Am J Environ Sci 4(5):445-453

Raport KOBIZE (2012) Krajowy bilans emisji $\mathrm{SO}_{2}$, NOX, CO, NMLZO, NH3, pyłów, metali ciężkich i TZO za lata 2009-2010 w układzie klasyfikacji SNAP i NFR. (in Polish)

Raport Syntetyczny, Inspekcja Ochrony Środowiska (IOŚ) (2011) Analiza stanu zanieczyszczenia powietrza pyłem PM10 i PM2,5 z uwzględnieniem składu chemicznego pyłu oraz wpływu źródeł naturalnych. Zabrze. in Polish. www.gios.gov.pl/zalaczniki/ artykuly/raport syntetyczny.pdf)

Rozporządzenia Ministra Środowiska z dnia 24 sierpnia (2012) w sprawie poziomów niektórych substancji w powietrzu.
Dziennik Ustaw Rzeczypospolitej Polskiej, W-wa, 18 września, 2012. (in Polish)

Silva PJ, Vawdrey EL, Corbett M, Erupe M (2007) Fine particle concentrations and composition during wintertime inversions in Logan, Utah, USA. Atmos Environ 41:5410-5422. doi:10.1016/j. atmosenv.2007.02.016

Tainio M, Kukkonen J, Nahorski Z (2010) Impact of airborne particulate matter on human health: an assessment framework to estimate exposure and adverse health effects in Poland. Arch Environ Prot 36(1):29-39

Unal YS, Toros H, Deniz A, Incecik S (2011) Influence of meteorological factors and emission sources on spatial and temporal variations of PM10 concentrations in Istanbul metropolitan area. Atmos Environ 45:5504-5513. doi:10.1016/j.atmosenv.2011.06.039

van der Wal JT, Janssen LHJM (2000) Analysis of spatial and temporal variations of PM10 concentrations in the Netherlands using Kalman filtering. Atmosph Environ 34(22):3675-3687

van den Elshout S, Léger K, Heich H (2013) CAQI Common Air Quality Index - Update with PM2.5 and sensitivity analysis. Science of the Total Environment. doi:10.1016/j.scitotenv.2013.10.060

Wallace J, Corr D, Kanaroglou P (2010) Topographic and spatial impacts of temperature inversions on air quality using mobile air pollution surveys. Science of the Total Environment 408:5086-5096

World Health Organization (WHO) (2002) World Health report: reducing risks. Promoting Healthy Life, Geneva

World Health Organization (WHO) (2005) Air quality guidelines for particulate matter, ozone, nitrogen dioxide and sulfur dioxide, Global Update

World Health Organization (WHO) (2008) Air quality and health — fact sheet no 313

Yonemura S, Kawashima S, Matsueda H, Sawa Y, Inoue S, Tanimoto H (2008) Temporal variations in ozone concentrations derived from principal component analysis. Theor Appl Climatol 92:47-58. doi: 10.1007/s00704-007-0314-4

Yoo H-J, Kim J, Yi S-M, Zoh K-D (2011) Analysis of black carbon, particulate matter, and gaseous pollutants in an industrial area in Korea. Atmos Environ 45:7698-7704. doi:10.1016/j.atmosenv. 2011.02.049

Zabalza J, Ogulei D, Elustondo D, Santamaría JM, Alastuey A, Querol X, Hopke PK (2007) Study of urban atmospheric pollution in Navarre (Northern Spain). Environ Monit Assess 134:137-151. doi:10.1007/ s10661-007-9605-6 